


\title{
Towards Improved Fluvial Sediment Impact Assessment (FSIA) approaches within Environmental Impact Assessments
}

\author{
Novi okvir za procjenu utjecaja riječnog sedimenta u \\ studijama utjecaja na okoliš
}

Water contaminated with fine sediment can be a primary risk to human and ecological health. Sediment impacts are, however, complex and difficult to assess in environmental and social impact assessments, especially where timescales are short. We outline a new process-based framework - Fluvial Sediment Impact Assessment (FSIA) - designed to anticipate and address sediment pollution problems in rivers which may result from development projects. We establish three general principles, six methodological steps, and several technical approaches that underpin the framework.

Advantages of the framework are that: it is process-based; it explicitly recognises sediment dynamics; it includes explicit reference to ecological receptors; it capitalises on well-established biomonitoring protocols; it encourages multi-disciplinary involvement; and it is based on substantial experience of major development projects. The new framework offers significant potential for more rigorous assessment of fluvial sediment conditions, before, during and after development activity, such as oil and gas pipeline crossings.

Keywords: fine sediment, fluvial sediment impact assessment, biomonitoring, agroecology, hidrology
Voda onečišćena finim sedimentom može biti velika opasnost za zdravlje ljudi i okoliš. No u studijama utjecaja na okoliš i stanovništvo komplicirano je i teško procijeniti utjecaje sedimenta, osobito kad je riječ o kratkim razdobljima. $U$ radu se opisuje novi procesni okvir - procjena utjecaja riječnih sedimenata, Fluvial Sediment Impact Assessment (FSIA) osmišljen za predviđanje i analizu problema onečišćenja riječnim sedimentima koji potječu od građevinskih projekata. Postavljaju se tri opća načela, šest metodoloških koraka i nekoliko tehničkih pristupa na kojima se okvir temelji.

Prednosti su okvira sljedeće: temelji se na procesima, izričito se oslanja na dinamiku sedimenta, uključuje eksplicitne referencije za ekološke receptore, služi se općeprihvaćenim protokolima bionadzora, potiče multidisciplinaran pristup te se zasniva na bogatom iskustvu u velikim građevinskim projektima. Novi okvir nudi velik potencijal strože procjene stanja riječnog sedimenta prije, tijekom i nakon građevinske aktivnosti, primjerice polaganja naftnih i plinskih cjevovoda u rijeke.

Ključne riječi: fini sedimenti, procjena utjecaja riječnih sedimenata, bionadzor, agroekologija, hidrologija

\footnotetext{
* This paper was presented on one of the recent meetings (2012-2014) of the Commission for Water Sustainability of the International Geographical Union (IGU).

* Rad je predstavljen na jednom od skupova Komisije za vode Međunarodne geografske unije (IGU) održanih u razdoblju 2012.-2014.
} 
HRVATSKI

GEOGRAFSKI

GLASNIK

77/2,7-31 (2015.)

\section{Introduction}

1. Uvod

\subsection{Importance of the problem}

Contaminated water is often seen as the world's main health risk. Suspended sediment is an integral part of the functioning of fluvial systems, and indeed may be found in high concentrations even in near-pristine rivers (e.g. Lawler and Brown,1992; Old et al., 2005; Grove et al., 2015), but it can be a problematic water pollutant because of associated contaminants (e.g. Meybeck et al., 2007; Weber et al., 2008; Wetzel et al., 2013); turbidity increases which reduce light reception (Fig. 1A) for ecosystems (Julian et al., 2008), and affect predator-prey interactions (Bilotta and Brazier, 2008); smothering and abrasion of organisms (Jones et al., 2012a, b); and deposition-driven reduction of oxygen supplies for eggs in redds (Sear et al., 2014). Indeed, in the

\section{1. Važnost problema}

Onečišćena voda često se smatra glavnom svjetskom opasnošću za zdravlje. Suspendirani sediment integralni je dio djelatnih riječnih sustava, a u velikim se koncentracijama može naći i u gotovo nedirnutim rijekama (Lawler i Brown, 1992; Old i dr., 2005; Grove i dr., 2015). No zbog s njim povezanih kontaminata može biti riječ o problematičnom onečišćivaču vode (Meybeck i dr., 2007; Weber i dr., 2008; Wetzel i dr., 2013) jer povećano zamućivanje koje smanjuje dotok svjetlosti (sl. 1A) u ekosustav (Julian i dr., 2008) utječe na interakcije grabežljivaca i plijena (Bilotta i Brazier, 2008), gušenje i ozljeđivanje organizama (Jones i dr., 2012a, 2012b), a taloženjem je uzrokovano i smanjivanje zalihe kisika za jaja u gnijezdima mrijesta (Sear i dr., 2014). Doista, kad je riječ o kakvoći vode, u

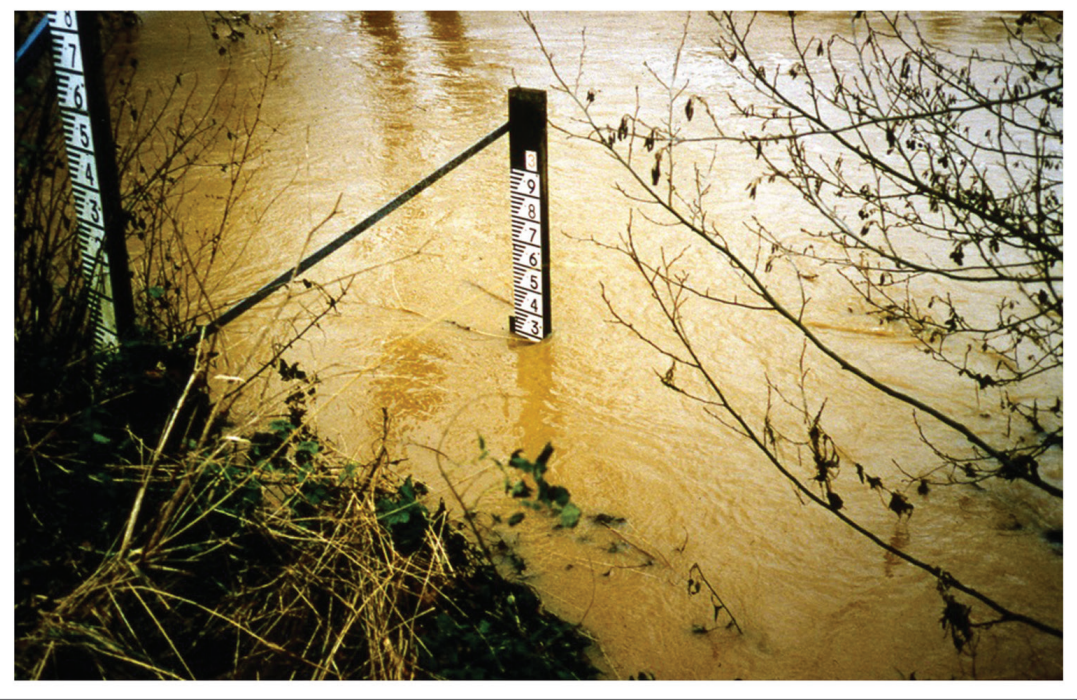

Fig. IA Highly turbid water at an Environment Agency river flow gauging station on the lowland River Alne, central England.

SI. 1A. Vrlo zamućen tok na mjernoj postaji Agencije za okoliš u nizinskom području rijeke Alne $u$ središnjoj Engleskoj.
USA suspended sediment is the primary cause of water quality violations (Gray and Gartner, 2009).

However, sediment impacts are complex and difficult to assess. This is especially true for short-term studies such as those within Environmental Impact Assessments (EIAs), Environmental and Social Impact Assessments (ESIAs) and Strategic Environmental Assessment (SEA), which cover a large
SAD-u je suspendirani sediment glavni uzrok kršenja zakona (Gray i Gartner, 2009).

No utjecaj sedimenata kompliciran je i teško ga je procijeniti. To se osobito odnosi na kratkoročna istraživanja poput onih koja procjenjuju utjecaj na okoliš (Environmental Impact Assessments, EIA), utjecaj na okoliš i društvo (Environmental and Social Impact Assessments, ESIA) te održivi utjecaj na okoliš (Strate- 


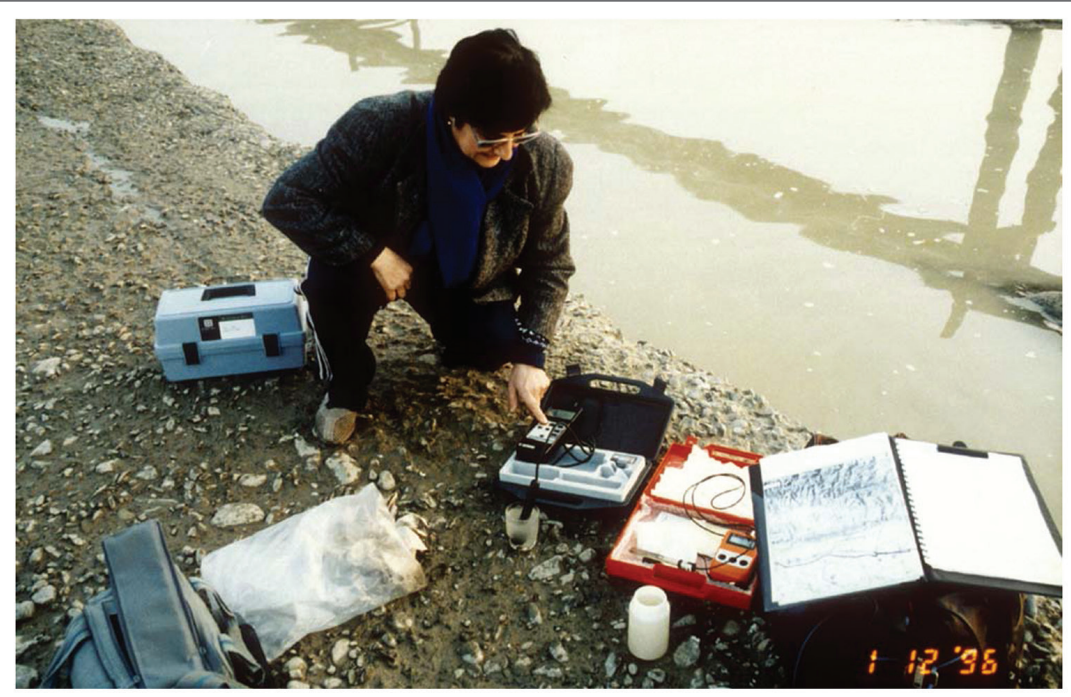

D. M. Lawler,

M. A. Wilkes

Towards Improved

Fluvial Sediment

Impact Assessment

(FSIA) approaches

within Environ-

mental Impact

Assessments

Novi okvir za procjenu utjecaja riječnog sedimenta u studijama utjecaja na okoliš

Fig. IB Using a hand-held portable Hach turbidity meter and other water quality sensors, in a turbid Azerbaijan river at a crossing site for a major international pipeline. Such one-off 'snapshot' turbidity measurements are vital at the early field reconnaissance stages of Environmental and Social Impact Assessments.

SI. IB. Uporaba ručnoga prenosivog Hachova mjerača zamućenosti i drugih senzora za određivanje kakvoće vode u zamućenoj azerbajdžanskoj rijeci na mjestu polaganja velikog naftovoda. Takva zasebna "jednokratna" mjerenja zamućenosti važna su u ranim izviđačkim fazama procjena utjecaja na okoliš i društvo(ESIA).

range of environmental areas (Lawler, 2004; Lawler, 2005a; Anifowose et al., 2011, 2012, 2014). In such investigations, key sediment issues are complex and include: dynamic variations in suspended sediment concentration (SSC) which are missed by "one-off" or infrequent water sampling strategies; spatial variability in SSC across the river cross-section, and in the downstream dimension, which control impacts and suspended sediment flux rates; and thresholds in the system above which impacts on ecosystems and communities escalate. These problems are especially important when assessing the likely impact on water resource quality of development activities, such as pipeline river crossings.

\subsection{Aims}

The aims of this paper therefore to address these research and environmental management gaps. The component objectives are to:

A. Examine sediment impacts on riverine ecology, especially fish and invertebrates, and demonstrate application of a new biomonitoring tool gic Environmental Assessment, SEA), pokrivajući širok raspon ekoloških područja (Lawler, 2004, 2005a; Anifowose i dr., 2011, 2012, 2014). U takvim istraživanjima glavna su pitanja u vezi sa sedimentima složena i uključuju dinamičke promjene u koncentraciji suspendiranog sedimenta (suspended sediment concentration, $\mathrm{SSC}$ ) koje se ne zamjećuju jednim ili slabo učestalim uzimanjem uzoraka, prostornu varijabilnost SSC-a preko cijelog presjeka rijeke te pragovi koncentracije iznad kojih se utjecaji na ekosustave i zajednice naglo povećavaju. Ta su pitanja osobito važna pri procjeni vjerojatnog utjecaja građevinskih radova, primjerice polaganja cjevovoda u rijeku, na kakvoću vodnih resursa.

\section{2. Ciljevi}

Cilj je ovog rada otkrivanje nedostataka u istraživanjima okoliša i upravljanju njime. To uključuje:

A. Proučavanje utjecaja sedimenta na riječnu ekologiju, osobito ribe i beskralješnjake te prikaz primjene novog alata za bionadzor 
B. Analyse high-resolution river suspended sediment transport dynamics, using new example datasets from different urban and rural riverine environments

C. Present novel data on sediment source dynamics, using river bank erosion as a key fluvial sediment contributor

D. Discuss sediment pollution impacts of major pipeline river crossings, based on our work in the UK, Russia and the Former Soviet Union Propose an initial framework for Fluvial Sediment Impact Assessment (FSIA) which incorporates future water quality appraisals, especially within EIAs, ESIAs and SEAs (Lawler et al., 1996; Lawler, 2003), and to serve as an input into newer policy initiatives.

We argue that a new framework is needed, including for ESIAs, which is based on realistic understandings of fine sediment dynamics, which are supported by high-frequency monitoring and detailed datasets on SSC variations and hysteretic responses. These reveal much more about system operation than averages or long-term values alone, which are typically relied upon in many Environmental and Social Impact Assessments.

\section{Fine sediment impacts and ecological implications}

Elevated concentrations of fine sediment carried in suspension or accumulated in river beds can exert a number of direct and indirect negative impacts on stream biota. Among these are impacts associated with contaminants attached to fine particles, such as nutrients, heavy metals and Persistent Organic Pollutants (POPs), which are not considered in detail here. Ecological responses to physical aspects of sediment pollution have been documented at all trophic levels, from primary producers to top predators.

Plants are predominantly impacted by reduced levels of Photosynthetically Active Radiation (PAR) due to light attenuation by suspended particles (Julian et al., 2008) and the smothering effects
B. Analizu dinamike suspendiranog sedimenta u rijeci novim primjerima iz različitih gradskih i seoskih riječnih okoliša

C.Predstavljanje novih podataka o dinamici izvora sedimenata naglašavajući eroziju riječne obale kao glavni izvor riječnog sedimenta

D.Raspravu o utjecaju onečišćenja sedimentom velikih cjevovoda položenih u rijeke te temeljeno na iskustvu autorâ ovog rada u Ujedinjenom Kraljevstvu, Rusiji i bivšemu Sovjetskom Savezu iznošenje okvira procjene utjecaja riječnog sedimenta (Fluvial Sediment Impact Assessment, FSIA) koja uključuje buduće procjene kakvoće vode, osobito u odnosu na EIA-e, ESIA-e i SEA-e (Lawler i dr., 1996; Lawler, 2003).

U radu se pokušava dokazati da je potreban nov okvir, uključujući i onaj za ESIA-u, utemeljen na razumijevanju dinamike finih sedimenata, podržan čestim nadzorom i podrobnim podacima o kretanju SSC-a i histeretskim reakcijama." Oni nam o sustavu otkrivaju mnogo više od prosječnih ili samo dugoročnih podataka koji su obično temelj studija utjecaja na okoliš ili društvo.

\section{Utjecaj finih sedimenata i ekološke posljedice}

Povećane koncentracije finih sedimenata koji se prenose u suspenziji ili su nataloženi u riječnom koritu na mnogo izravnih i neizravnih načina negativno utječu na život u vodotoku. Među njima su utjecaji povezani s onečišćivačima učvršćenim za sitne čestice, primjerice hranivima, teškim metalima i postojanim organskim onečišćivačima (Persistent Organic Pollutant, POP), kojima se ovaj rad neće podrobno baviti. Ekološke reakcije na fizikalne oblike onečišćenja sedimentima dokumentirane su na svim trofičkim razinama, od primarnih proizvođača do vrhovnih grabežljivaca.

$\mathrm{Na}$ biljke najvećim dijelom utječu smanjene razine fotosintetski aktivnog zračenja (Photosynthetically Active Radiation, PAR), što je posljedica smanjene količine svjetlosti zbog suspendiranih čestica (Julian

\footnotetext{
* Histeretska reakcija (pridjev od grč. hysteréo što znači kasniti, zaostajati) - Reakcija sustava koja ne ovisi samo o magnitudi sadašnjeg vanjskog utjecaja već i o prethodnom stanju sustava. (objašnjenje engleskog pojma na hrvatskom)
} 
of deposited sediments, among other factors (Jones et al., 2012a). Fish and invertebrate consumers are affected, in turn, by reduced resources, in addition to direct impacts associated with gill abrasion, stress and increased susceptibility to disease (Reid et al., 2003; Jones et al., 2012b). Turbidity alters predator-prey interactions in complex ways, increasing prey susceptibility to predation and reducing reaction distances for predators depending on the species involved (Bilotta and Brazier, 2008; Jones et al., 2012b). The combined severity of ill effects (SEV) suffered by fish have been studied for a number of species (Newcombe and Jensen, 1996) and depend on the characteristics of pollution events described by Concentration-Duration-Frequency (CDF) curves (Schwartz et al., 2008). The suspended sediment concentration (SSC) limit of $25 \mathrm{mg} \mathrm{l}^{-1}$ set by the EC Freshwater Fish Directive, therefore, has "limitationsand" should be replaced by a dynamic limit reflecting the complexity of the sediment problem and the need to consider rivers and glacioi-fluvial systems with naturally high suspended sediment concentrations and loads (e.g. Old et al., 2005; Bilotta et al., 2012; Grove et al., 2015; Lawler, 2015).

Some riverine species have evolved to withstand temporarily elevated SSC as part of a quasi-predictable annual sediment regime (Grove et al., 2015). They are less well adapted, however, to sudden high magnitude sediment pollution events that are often associated with episodes of very low dissolved oxygen due to the high oxygen demand of fine sediment (Alonso et al., 1996). Oxygen is also a key factor in the classic model of fine sediment pollution, known as "colmation". Colmation describes the process leading to clogging of river beds with fine sediments due to gravitational settling, advection and further infiltration deep into the bed matrix (Boano et al., 2014; Lawler et al., 2009). This limits oxygen supply to salmonid eggs and restricts the hyporheic flow that is crucial for processing contaminants and flushing out waste products (Greig et al., 2005, 2007; Sear et al., 2014). It also limits the emergence of recently hatched fry by creating a seal (Sear et al., 2008). Aquatic macroinvertebrates are affected by similar processes and for this reason European authorities have begun to use indices to describe the sediment sensitivity i dr., 2008) i, uz ostale čimbenike, zagušujućeg djelovanja nataloženih sedimenata (Jones i dr., 2012a). Osim izravnim utjecajem povezanim s abrazijom škrga, stresom i povećanim rizikom od obolijevanja riblji i beskralješnjački potrošači ugroženi su i ograničenim resursima (Reid i dr., 2003; Jones i dr., 2012b). Zamućenost na složene načine mijenja interakcije lovaca i plijena povećavajući ugroženost plijena i smanjujući udaljenosti potrebne za reakciju grabežljivaca ovisno o uključenim vrstama (Bilotta i Brazier, 2008; Jones i dr., 2012b). Ozbiljnost kombiniranih negativnih učinaka (severity of ill effects, SEV) na ribe istražena je za brojne vrste (Newcombe i Jensen, 1996), a ovisi o značajkama onečišćenja opisanih krivuljama koncentracije, trajanja i učestalosti (concentration- $d u$ ration-frequency, CDF) (Schwartz i dr., 2008). Granica koncentracije suspendiranog sedimenta (SSC) od $25 \mathrm{mg}^{-1}$ koju je postavila „Direktiva o kakvoći vode za slatkovodne ribe" Europske Unije ima dva ograničenja i valjalo bi je zamijeniti dinamičkom granicom koja odražava složenost problema sedimenta te bi trebalo uzeti u obzir rijeke i ledenjačko-riječne sustave s prirodno velikim koncentracijama i opterećenjem suspendiranog sedimenta (Old i dr., 2005; Bilotta i dr., 2012; Grove i dr., 2015; Lawler, 2015).

Neke riječne vrste evoluirale su tako da mogu izdržati privremeno povišen SSC kao dio kvazipredvidljivoga godišnjeg sedimentnog režima (Grove i dr., 2015). No manji je broj dobro prilagođen iznenadnim velikim onečišćenjima sedimentom, često povezanim s epizodama vrlo male količine otopljenoga kisika zbog velike potrebe za kisikom finog sedimenta (Alonso i dr., 1996). Kisik je također najvažniji čimbenik u klasičnome modelu onečišćenja finim sedimentom, tzv. kolmacijom. Kolmacija opisuje proces koji vodi zatrpavanju riječnih korita finim sedimentima uzrokovan gravitacijskim taloženjem, advekcijom i daljnjom infiltracijom duboko u osnovicu korita (Boano i dr., 2014; Lawler i dr., 2009). Tako se ograničava dotok kisika za jaja salmonida i hiporeični dio toka, ključan za procesuiranje i ispiranje onečišćivača (Greig i dr., 2005, 2007; Sear i dr., 2014). Stvaranje čepova također ograničava izlazak riblje mlađi (Sear i dr., 2008). Slični procesi djeluju na vodene makrobeskralješnjake pa su zbog toga europske vlasti počele upotrebljavati pokazatelje za opisivanje osjetljivosti beskralješnjačkih zajednica na sedimente (Extence i dr., 2013). Ovisno o profilu i kapacitetu
D. M. Lawler, M. A. Wilkes

Towards Improved

Fluvial Sediment Impact Assessment (FSIA) approaches within Environmental Impact Assessments

Novi okvir za procjenu utjecaja riječnog sedimenta u studijama utjecaja na okoliš 
of invertebrate communities (e.g. Extence et al., 2013). Certain sites will be more susceptible than others to clogging depending on the river's capacity to transport material, which is reflected in local and upstream distributions of stream power (Barker et al., 2009; Bizzi and Lerner, 2012, 2015).

Particle size is an important determinant of likely ecological impacts. Coarser fractions of the suspended sediment load are more likely to be deposited, increasing the erodibility of macrophyte beds (Jones et al., 2012a) and clogging redds (Greig et al., 2005), whereas finer particles $(<2 \mu \mathrm{m})$ are more likely to affect the respiratory organs and feeding apparatus of fish and invertebrates (Bilotta and Brazier, 2008). Clay-sized $(<4 \mu \mathrm{m})$ particles can be trapped by periphyton, reducing its attractiveness to grazing organisms (Graham, 1990). Particle size has also been implicated in the smothering of invertebrates. In particular, the ability of some taxa to excavate themselves from fine sediment deposits is significantly affected by particle size (Wood et al., 2005).

\section{River sediment transport dynamics: the "Sediment Transience" issue.}

"Snapshot" river water sampling or one-off turbidimetric measurements, as in Figure 1B, can be very useful to determine instantaneous values for turbidity or SSC, especially on reconnaissance fieldwork. However, there is a key sediment transience issue to fully recognise too. Turbidity and SSC values vary strongly over time - often over many orders of magnitude (e.g. Walling, 1992; Old et al., 2005). Particulate concentrations, even at a single site, vary non-linearly with river flow levels, upstream sediment-source release and catchment processes ), and antecedent conditions. One-off values, therefore, will almost never be representative, and they often form substantial underestimates of "true" fluvial sediment transport rates.

Importantly, in development-impact assessment terms, such low-flow sediment reconnaissance sampling may create the impression that the river system is "clean" and possesses resilience (or "headroom") to accept further fine sediment inputs as a rijeke neki su lokaliteti osjetljiviji na začepljivanje, što se odražava na lokalnu i uzvodnu raspodjelu snage toka (Barker i dr., 2009; Bizzi i Lerner, 2012, 2015).

Važna odrednica mogućih ekoloških utjecaja veličina je čestica sedimenta. Za grublje frakcije suspendiranog sedimenta vjerojatnije je da će se nataložiti te tako povećati erozivnost makrofitnih podloga (Jones i dr., 2012a) i začepiti nakupine mrijesta (Greig i dr., 2005), a za sitnije je čestice $(<2 \mu \mathrm{m})$ vjerojatnije da će utjecati na dišne organe i hranidbeni sustav riba i beskralješnjaka (Bilotta i Brazier, 2008). Čestice veličine gline $(<4 \mu \mathrm{m})$ mogu se uhvatiti za perifiton te ga učiniti manje privlačnim za organizme koji se njime hrane (Graham, 1990). Veličina čestica također se spominje kao uzrok zagušivanja beskralješnjaka. Ona osobito utječe na sposobnost nekih svojta (taksona) da se iskopaju iz nataloženih finih sedimenata (Wood i dr., 2005).

\section{Dinamika riječnih sedimenata: pitanje „prolaznosti sedimenata”}

"Jednokratno" uzimanje uzoraka iz rijeke ili zasebno mjerenje zamućenja, kao na slici 1B, može biti vrlo korisno za određivanje trenutačnih vrijednosti zamućenja ili SSC-a, osobito pri terenskim izviđanjima. No u obzir svakako valja uzeti i iznimno važnu „prolaznost sedimenata”. Vrijednosti zamućenja i SSC-a vremenski su vrlo promjenjive - nerijetko u rasponu od mnogo redova veličine (Walling, 1992; Old i dr., 2005). Koncentracije čestica, čak i na jednome mjestu, nelinearno se mijenjaju s promjenama razina riječnog toka,ispuštanjem sedimenata na uzvodnom izvoru, procesima u poriječju te prijašnjim uvjetima. Zbog toga zasebna mjerenja gotovo nikad neće biti reprezentativna i nerijetko rezultiraju znatnim podcjenjivanjem „prave” brzine pronosa riječnog sedimenta.

Kad je riječ o procjenama građevinskih utjecaja, vrlo je važno napomenuti da takvo izviđačko uzorkovanje sedimenta u trenutku malog protoka može stvoriti dojam da je riječni sustav „čist” te da raspolaže otpornošću (ili „slobodnim prostorom”) za primanje dodatnog dotoka finih sedimenata kao posljedice građevinskih projekata bez zamjetljivog oštećenja 
result of development projects without appreciable damage to ecosystems. In fact, the "true" maximum and mean levels of SSC or suspended sediment flux will likely be much higher. The time series will also punctuated by exceptional flood-related suspended sediment events. Sediment levels could thus become environmentally critical when further suspended sediment loads are added from development projects at construction and post-construction operation stages. In addition, difficulties are compounded because sediment flux events ("pulsing") may also occur independently of river flow events, especially in mountain and glacial meltwater basins (e.g. Lawler, 2005a; Old et al., 2005), linked to subglacial channel switching or ice-collapse events.

Hysteresis is widespread in sediment transport systems, which adds further complications for prediction. For example, SSC generally tends to increase positively with river flow (e.g. Fig. 2), following rainfall, snowmelt or glacier ablation events (Lawler and Brown, 1992; Old et al., 2005). However, clockwise hysteresis is often observed (Fig. 2A), where SSC rises with discharge but peaks ahead of the flow maximum. This has been explained by several processes, but proximal sediment sources which are transported into the stream quite quickly is one driver of this "first-flush" effect (Fig. 2A). In addition, although Figure $2 \mathrm{~A}$ shows a tendency for positive, clockwise hysteresis in sediment responses, the curves are complicated by periods of anticlockwise behaviour.

Figure 2B, however, shows high frequency 15-minute turbidity data for the highly urbanised River Tame catchment, central UK, which demonstrates that the turbidity response is very strongly negatively hysteretic, i.e. opposite to the classic first-flush hypothesis. Here, most of the fine sediment is coming through late in the storm, after the flow peak, and Lawler et al. $(2006 a, 2006 b)$ found this to be the characteristic dynamic for this urban system. Amongst other causes (Lawler, in prep.) such lagged responses have been ascribed to sewage inputs entering the river from treatment plants or combined sewer overflows when their capacities are exceeded late in a storm event.

Also, the rates at which SSC rises during flow events are not fully predictable in advance. For example, note in Figure 2A the considerable charac- ekosustava. Zapravo, „pravi” maksimum i srednje razine SSC-a ili suspendiranoga sedimentnog toka vjerojatno će biti mnogo viši. $\mathrm{Na}$ vremenske nizove podataka također će utjecati izvanredni događaji povezane sa suspendiranim sedimentima tijekom poplava. Zato bi razine sedimenta mogle postati ekološki kritične kad se opterećenju građevinskih i konstrukcijskih sedimenata te u poslijekonstrukcijskoj fazi pribroji dodatno sedimentno opterećenje. Usto, te se poteškoće umnožavaju jer se izvanredni događaji u toku sedimenta (,pulsiranje”) mogu zbivati neovisno o događajima u riječnom toku, osobito u planinskim i ledenjačkim poriječjima (Lawler, 2005a; Old i dr., 2005), što je povezano s promjenom podledenjačkih kanala ili urušavanjem leda.

Histereza je veoma rasprostranjena u sedimentnim transportnim sustavima, što dodatno usložnjava predviđanje. Primjerice SSC se općenito pozitivno povećava s protokom (npr. sl. 2), poslije kiša, otapanja snijega ili ledenjačkom ablacijom (Lawler i Brown, 1992; Old i dr., 2005). No često se opaža histereza u smjeru kazaljke sata (sl.2A), gdje se SSC povećava pražnjenjem, ali vrhunac ima prije maksimuma toka. To se objašnjava s nekoliko procesa; jedan je od razloga tog efekta "prvog ispiranja” (sl. 2A) taj što bliži izvori sedimente $\mathrm{u}$ tok prenose vrlo brzo. Usto, iako slika $2 \mathrm{~A}$ u reakcijama sedimenta prikazuje tendenciju pozitivne histereze u smjeru kazaljke sata, krivulje usložnjavaju razdoblja ponašanja u smjeru suprotnom kazaljci sata.

Slika 2B prikazuje visokoučestale 15 -minutne podatke zamućenja poriječja visokourbanizirane rijeke Tame u središnjem dijelu Velike Britanije te se vidi da je zamućenje histeretski vrlo negativno, tj. suprotno klasičnoj hipotezi prvog ispiranja. Većina finog sedimenta ovdje protječe pri kraju oluje, nakon maksimalnog toka, a Lawler i dr. (2006a, 2006b) ustanovili su da je to karakteristična dinamika tog urbanog sustava. Među ostalim uzrocima (Lawler, u pripremi) takve se zakašnjele reakcije pripisuju kanalizacijskim ispustima u rijeke iz postrojenja za obradu voda ili kombiniranom preljevu kanalizacijskih voda kad im se pri kraju oluje premaši kapacitet.

Također, brzina porasta SSC-a tijekom izvanrednih zbivanja u toku ne može se posve predvidjeti. Primjerice na slici $2 \mathrm{~A}$ valja obratiti pozornost na znatno rasipanje značajki i nelinearnost reakcije tijekom dvaju događaja na rijeci Wharfe u Ujedinjenom Kraljev-
D. M. Lawler, M. A. Wilkes

Towards Improved

Fluvial Sediment Impact Assessment (FSIA) approaches within Environmental Impact Assessments

Novi okvir za procjenu utjecaja riječnog sedimenta u studijama utjecaja na okoliš 
HRVATSKI

GEOGRAFSKI

GLASNIK

77/2,7-31 (2015.)

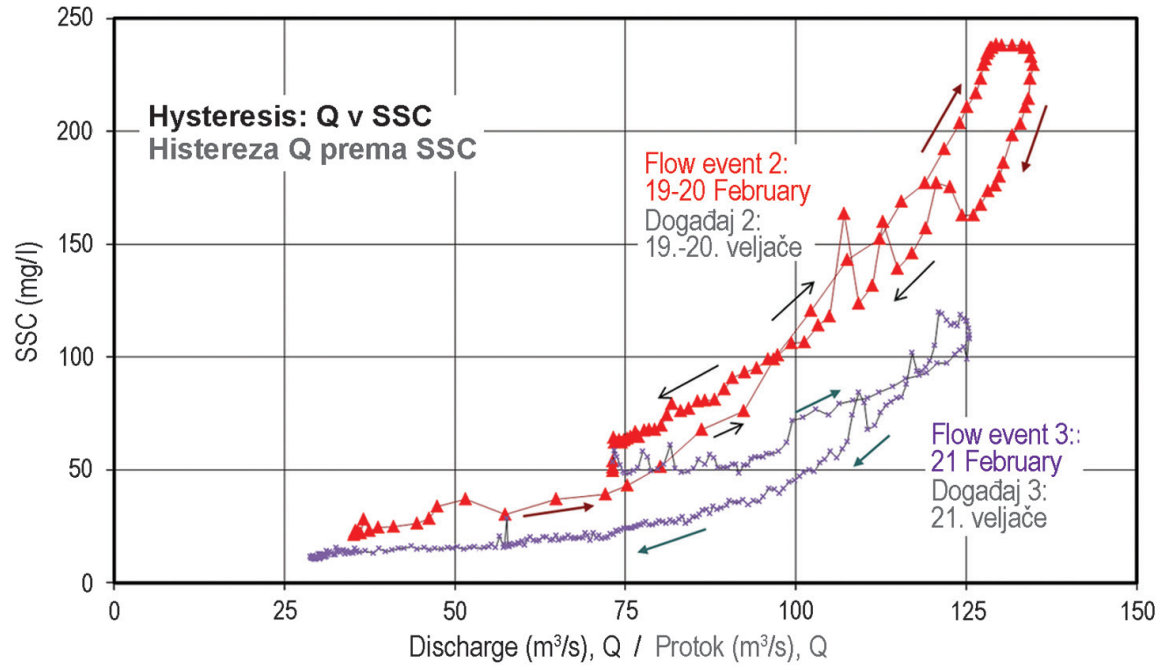

Fig. 2A Suspended sediment concentration (SSC) response for two river flow events (19-20 February and 21 February, 1997 for the River Wharfe at Tadcaster, Yorkshire, UK. Note the largely positive hysteresis response, but also the incorporation of transient negative hysteresis elements in the dynamics.

SI. 2A. Koncentracije suspendiranog sedimenta (SSC) kao reakcije na dva događaja s različitim protokom (19./20. veljače i 21. veljače 1997.) rijeke Wharfe u Tadcasteru u Yorkshireu u Ujedinjenom Kraljevstvu. Obratite pozornost na uglavnom pozitivnu reakciju histereze, ali i postojanje prolaznih negativnih histeretskih elemenata $u$ dinamici događaja.

Event $19 \mathrm{c1} .28$ January 2002. James Bridge, River Tame, UK

Događaj $19 \mathrm{c1}$. od 28. siječnja 2002., most James, rijeka Tame, VB

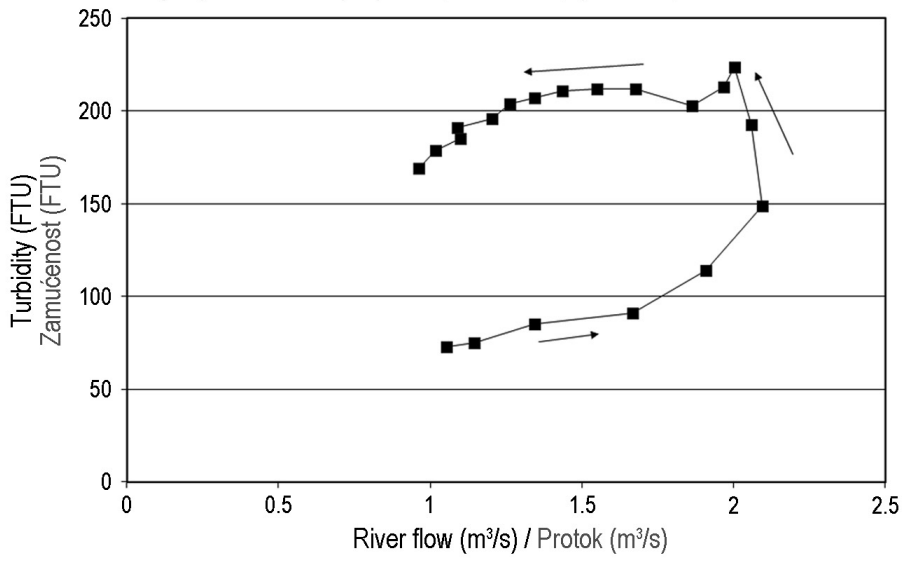

Fig. 2B Fully developed negative, anticlockwise, hysteresis in Turbidity response during a streamflow event on the urbanised upper River Tame in Birmingham, UK. Storm of 28 January 2002. FTU = Formazin Turbidity Units. $Q=$ river flow rate in $\mathrm{m}^{3} \mathrm{~s}^{-1}$. See Lawler et al. (2006a).

SI. 2B. Posve razvijena negativna histereza suprotna kazaljci sała u reakciji zamućenosti toka u urbaniziranome gornjem dijelu rijeke Tame $\cup$ Birminghamu $\cup$ Ujedinjenom Kraljevstvu. Oluja od 28. sjječnja 2002. FTU = formazinske jedinice zamućenja; $Q$ = riječni protok $\cup^{3} \mathrm{~s}^{-1}$. Vidi Lawler i dr. (2006a). 
teristic scatter and non-linearity in response during the two flow events for the River Wharfe, UK. Furthermore, between successive flow events, even over similar discharge ranges (e.g. Figure 2A; 75 - 125 $\mathrm{m}^{3} \mathrm{~s}^{-1}$ range), suspended sediment responses can be very different. Figure 2A, for instance, shows a sediment exhaustion effect, where restrictions in sediment supply for the second event (22 February) result in lower SSC for a given river discharge.

\section{Sediment source dynamics}

It is desirable to identify the sources of problematic fine sediment, so that they can be managed appropriately. For example, sediment sources and slope erosion rates have been estimated as a first approximation using simple empirical tools such as the RUSLE (Revised Universal Soil Loss Equation) (Rymszewicz et al., 2014). River bank erosion upstream can also be a key source of fine sediment entering river systems (e.g. Lawler, 2008; Collins et al., 2010, 2013; Massoudieh et al., 2013). However, to identify and understand the relative dominance of the many processes which drive the bank erosion system (e.g. Lawler, 2005b, 2008) we need to know when bank erosion events occur with respect to the wide range of suspected controlling variables. Such exercises also provide useful knowledge to guide the appropriate remediation works necessary. However, the coarse temporal resolution of conventional manual river bank resurvey techniques may not provide a suitable basis for identifying the processes and different sediment sources.

To address this erosion and sediment production measurement problem, Lawler (1992) invented the first sensor to monitor erosion automatically, namely - the Photo-Electronic Erosion Pin (PEEP) system, and more, recently, the PEEP3T system (Lawler 2005b, 2008). PEEP systems improve process identification capabilities, through defining individual event dynamics. The newer version (PEEP3T) also incorporates a Thermal Consonance Timing (TCT) principle facilitated by thermistors in the sensor. The two measurement principles combined (photoelectronic; and thermal consonance timing) allow erosional and depositional events to be detected at day or night at $\sim 1 \mathrm{~mm}$ stvu. Usto, među dva uzastopna događaja, čak i uz slične raspone protoka (vidi sliku 2A; raspon $75-125 \mathrm{~m}^{3}$ $\left.\mathrm{s}^{-1}\right)$, količina suspendiranog sedimenta može biti vrlo različita. Na primjer slika $2 \mathrm{~A}$ prikazuje efekt iscrpljenja sedimenta gdje ograničenja donosa sedimenta $u$ drugom događaju (22. veljače) za posljedicu imaju niži SSC za jednaki protok vode.

\section{Dinamika izvora sedimenata}

Poželjno je ustanoviti izvore problematičnoga finog sedimenta kako bi se njime moglo upravljati na najbolji način. Primjerice izvori sedimenta i brzina erozije padina procijenjeni su u prvoj aproksimaciji jednostavnim empirijskim alatima poput revidirane jednadžbe univerzalnoga gubitka tla (Revised Universal Soil Loss Equation, RUSLE) (Rymszewicz i dr., 2014). Erozija riječne obale uzvodno također može biti važan izvor finog sedimenta koji ulazi u riječne sustave (Lawler, 2008; Collins i dr., 2010, 2013; Massoudieh i dr., 2013). No kako bi se ustanovili i shvatili razmjerno prevladavajući među brojnim procesima koji utječu na sustav erozije obala (npr. Lawler, 2005b, 2008), potrebno je znati kada dolazi do erozije obale s obzirom na široku paletu mogućih čimbenika. Takve aktivnosti također nude korisne smjernice za radove potrebne za ispravljanje stanja. No vrlo gruba vremenska razlučivost uobičajenih ručnih tehnika ponovnog istraživanja obala možda ne nudi odgovarajući temelj za prepoznavanje procesa i različitih izvora sedimenta.

Kako bi se pozabavio tim problemom mjerenja erozije i stvaranja sedimenta, Lawler (1992) je izumio prvi senzor za automatski nadzor erozije, tzv. sustav fotoelektroničkoga erozijskoga klina (Photo-Electronic Erosion Pin, PEEP), a potom i sustav PEEP3T (Lawler, 2005b, 2008). Sustavi PEEP poboljšavaju mogućnosti prepoznavanja procesa definiranjem dinamike pojedinih događaja. Novija inačica (PEEP3T) uključuje i načelo tempiranja toplinske konzonancije (Thermal Consonance Timing, TCT) omogućeno termistorima u senzoru. Dva kombinirana načela mjerenja (fotoelektroničko i tempiranje toplinske konzonancije) omogućuju da se erozijski i taložni događaji otkrivaju danju i noću s razlučivošću $\sim 1 \mathrm{~mm}$ (Lawler, 2005b, 2008). Veliči-
D. M. Lawler, M. A. Wilkes

Towards Improved

Fluvial Sediment Impact Assessment

(FSIA) approaches within Environmental Impact Assessments

Novi okvir za procjenu utjecaja riječnog sedimenta u studijama utjecaja na okoliš 
GEOGRAFSKI

GLASNIK

77/2,7-31 (2015.) resolution (Lawler, 2005b; 2008). The magnitude and timing of individual erosion events can be resolved, too, in relation to changes in the suspected controlling variables (e.g. channel hydraulics during high flows; geotechnically-induced bank collapse; or weathering, desiccation and freeze-thaw activity).

Figure 3A shows an example PEEP3T time series which reveals a major bank erosion event. The system clearly identifies the magnitude of the erosion, and the precise flow peak, of a sequence of three peaks, responsible. Indeed, the system confirms the precise erosion event timing at 15.30 GMT on 6 November - just before the flow maximum.

Capturing such dynamic changes is crucial to accurate assessment of baseline conditions and reasonable prediction of future impacts of major developments such as dam construction, urbanisation projects or pipeline river crossings. PEEP systems can provide improved knowledge of sediment-source dynamics and controlling processing on which to decide on appropriate management strategies and policies, including for ESIA applications.

PEEP3T systems have now been applied in many bank and soil erosion systems internationally by at least 30 research groups (Figure 3B), and also to additional landscape instability problems such as soil erosion, switching estuarine systems and dynamic tidal mudbanks (e.g. Mitchell et al. 2003; Lawler 2005b; Lawler, 2008), coastal sedimentation problems, including US Geological Survey work on accretion rates in San Francisco Bay.

PEEP3T systems are useful because these data on the timing and magnitude of erosion and deposition events and rates, in relation to data on fluctuations in the driving forces (e.g. high discharges or shear stresses or turbulence; tidal water-level cycles; weathering processes; wind action), can greatly help to identify the influential processes and quantify their control. Such datasets are also useful for building, testing, improving and validating models in the field or laboratory. Furthermore, once the controlling processes are identified, management can be more securely based. PEEPs are applicable na i vrijeme pojedinih erozijskih događaja također se mogu razlučiti prema promjenama u mogućim nadzornim čimbenicima (npr. kanalnom hidraulikom tijekom velikih protoka, geotehnički pokrenutim urušavanjem obale ili trošenjem, isušivanjem te djelovanjem zaleđivanja i odleđivanja).

Slika 3A prikazuje primjer vremenskog niza PEEP3T koji otkriva velik događaj obalne erozije. Sustav jasno prepoznaje magnitudu erozije i točan vrhunac odgovornoga vodenog vala u nizu od tri vrhunca. Doista, sustav potvrđuje točni trenutak erozijskog zbivanja u 15.30 GMT 6. studenoga neposredno prije maksimuma toka.

Bilježenje takvih dinamičkih promjena najvažnije je za točnu procjenu temeljnih uvjeta i razumno predviđanje utjecaja velikih zahvata poput konstrukcije brana, urbanizacijskih projekata ili prolaska cjevovoda kroz rijeku. Sustavi PEEP mogu ponuditi bolje podatke o dinamici i nadzoru procesa izvora sedimenta kao temelju za odgovarajuće upravljačke strategije i politike, među njima i ESIA-e.

Sustave PEEP3T danas na nekoliko mjesta na svijetu primjenjuje barem trideset istraživačkih skupina (sl. 3B) u sustavima nadzora obala i erozije tla te za dodatne probleme s nestabilnošću krajolika poput erozije tla, premještanja estuarijskih sustava i dinamičkih muljevitih morskih obala (Mitchell i dr., 2003; Lawler, 2005b, 2008), problema s obalnom sedimentacijom, uključujući i rad Američke geološke uprave (US Geological Survey) o brzini taloženja u zaljevu San Francisca.

Sustavi PEEP3T korisni su jer takvi podaci o vremenima i brzinama magnitude erozije te taloženja uz podatke o promjenama pokretačkih sila (npr. velikih vodnih valova, stresova smicanjem ili turbulencije, ciklusa morskih mijena, erozije i djelovanja vjetra) mogu uvelike pomoći prepoznavanju utjecajnih procesa i kvantificiranju njihova opsega. Takve zbirke podataka mogu biti korisne za građevinsko testiranje, poboljšavanje i validaciju modela na terenu ili u laboratoriju. Nadalje, kad se ustanove procesi, temelji upravljanja postaju mnogo čvršći. PEEPovi se mogu primijeniti u brojnim okolnostima te se uspješno upotrebljavaju, primjerice za mjerenje erozije i taloženja na riječnim obalama, vododerinama, kanalima i drenažnim jarcima, kao i muljevitim obalama, plažama te u pokusima s brzicama. 
Fig. $3 A$ and $3 B$ Automated sediment erosion and deposition monitoring with the Photo-Electronic Erosion Pin system (Lawler, 1992) and the PEEP3T Thermal Consonan-

ce Timing (TCT) system of Lawler (2005c; 2008). (A) River bank erosion event detected automatically and precisely by the PEEP3T -TCT system. Note the use of the Thermal Consonance Timing concept example. International applications of the PEEP system and the PEEP3T Thermal Consonance Timing (TCT) system of Lawler (2005c; 2008) for automatic erosion, sediment generation and deposition dynamics studies. (B) More than 35 research groups and geological, environmental and applied organisations worldwide now use the PEEP3T methodology for automated monitoring, and improved understanding and management of erosion and deposition problems in a range of fluvial, estuarine, coastal and nival environments.

SI. 3A. i 3B. Automatski nadzor erozije i taloženja sedimenata sustavom fotoelektroničkoga erozijskoga klina (Photo-Electronic Erosion Pin) (Lawler, 1992) i Lawlerovim (2005c, 2008) sustavom PEEP3T tempiranjem toplinske konzonancije (Thermal Consonance Timing, TCT). (A) Događaj erozije riječne obale automatski je i točno predviđen sustavom PEEP3T-TCT. Obratite pozornost na uporabu primjera koncepta TCT. Međunarodna primiena sustava

PEEP i Lawlerova $(2005$ c, 2008) sustava PEEP3T tempiranja toplinske konzonancije (Thermal Consonance Timing, TCT) za automatska istraživanja erozije, nastanka sedimenata i dinamike taloženja. (B) Više od 35 istraživačkih skupina te geološke, ekološke i slične organizacije danas upotrebljavaju metodologiju PEEP3T za automatski nadzor te poboljšano razumijevanje i upravljanje erozijskim i taložnim problemima u različitim riječnim, estuarijskim, obalnim i snježnim okolissima.

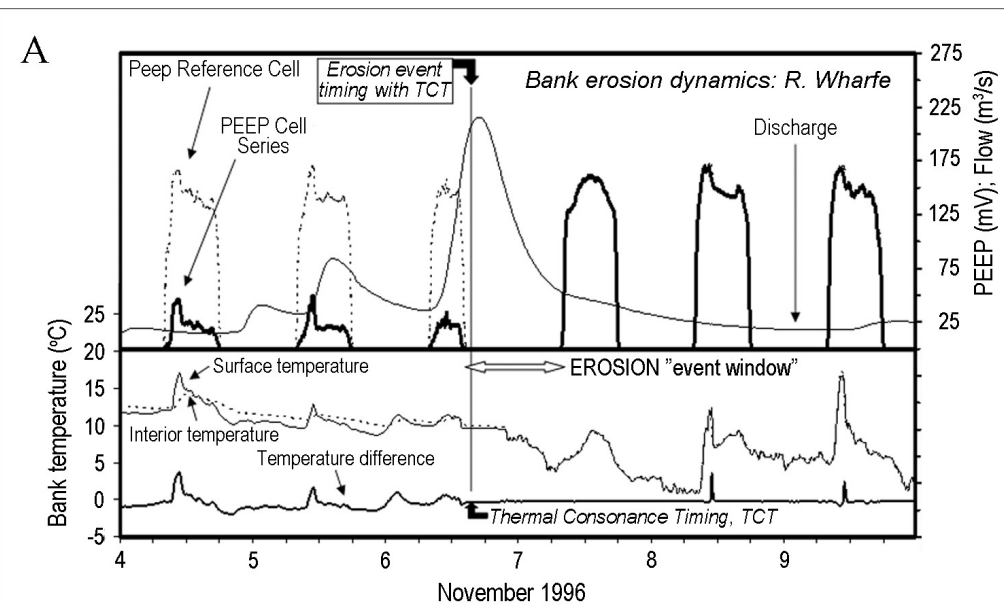

D. M. Lawler, M. A. Wilkes

Towards Improved

Fluvial Sediment

Impact Assessment

(FSIA) approaches within Environmental Impact

Assessments

Novi okvir za procjenu utjecaja riječnog sedimenta u studijama utjecaja na okoliš
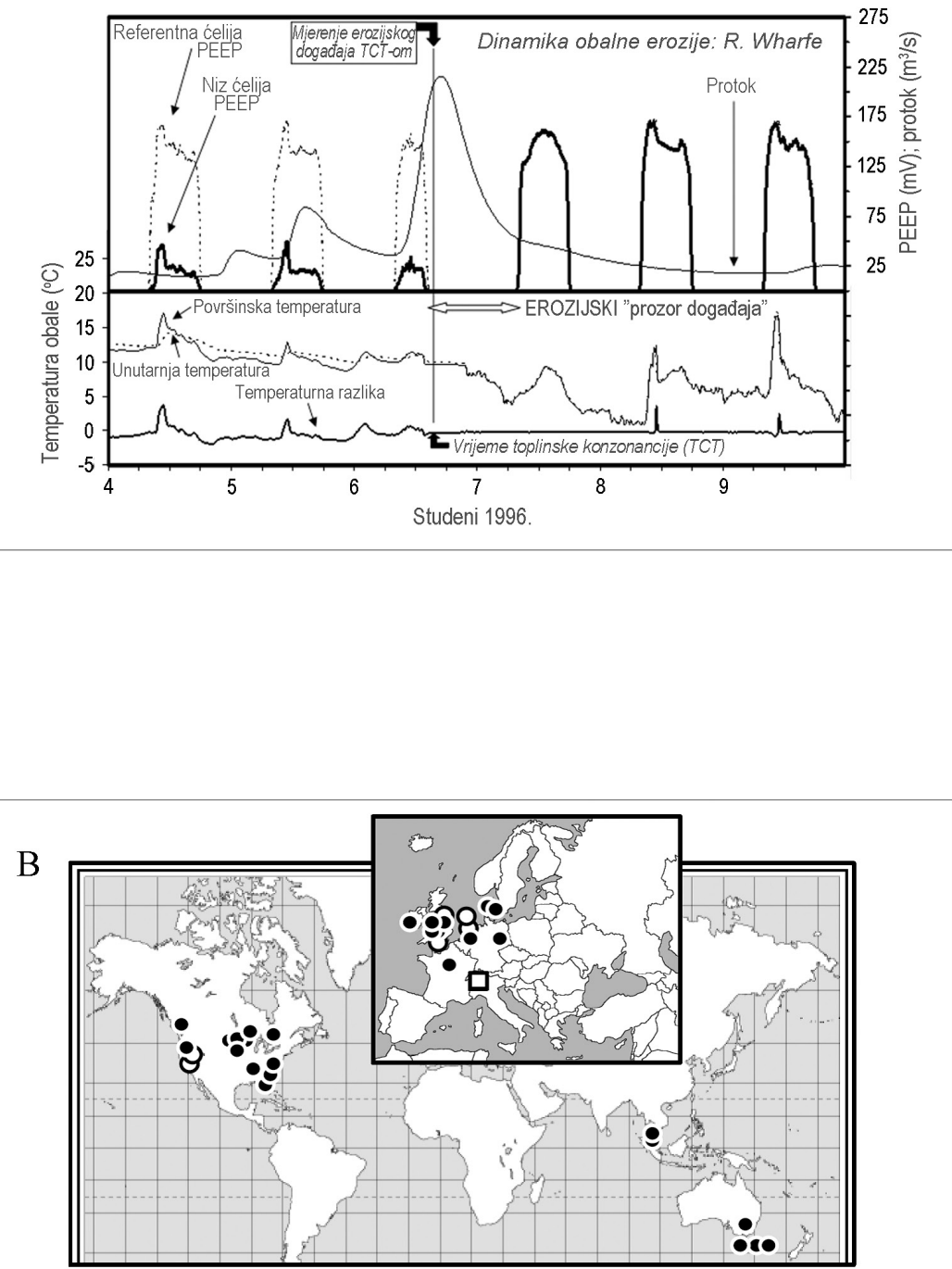

- Fluvial erosion/deposition Riječna erozija/taloženje

Coastal/estuarine Obalna/estuarijska
Snow accumulation/ablation Akumulacija i ablacija snijega 
GEOGRAFSKI

GLASNIK

77/2,7-31 (2015.) to many contexts, and have been deployed successfully, for example, to measure erosion and deposition on river banks, gullies, canals and drainage ditches, as well as tidal mudbanks, beaches and in flume experiments.

\section{Towards a new framework for FSIA: Fluvial Sediment Impact Assessment}

\subsection{Design}

Sediment system complexity, which has now been recognised globally with over 25 years of computerised sediment data acquisition, shows that more robust approaches and methodologies are needed to fully define sediment fluxes and landscape dynamics with respect to driving forces. This also applies to such studies within EIAs and ESIAs, which need to show that the planned development project will not impact detrimentally, for example, on fluvial, environmental or pollution processes - nor be adversely affected by natural forces (cf. Fukushima 2011 incident). Hence, we outline here a new Fluvial Sediment Impact Assessment (FSIA) framework (Fig. 4). It attempts to link effects of development projects (e.g. pipeline river crossings) on fine sediment processes and then to ecological responses, and shows where each monitoring technique can be used.

To guide the new FSIA framework, we establish and discuss the following below:

- three general principles;

- six methodological steps; and

- several technical approaches.

FSIA involves the combination of continuous monitoring of water quantity and quality, hydromorphological data collection and analysis, and biomonitoring. FSIA can be used as an adaptive, risk-based framework and should ideally be applied in a multiple Before-After-Control-Impact (mBACI) study design.

\section{Ususret novom okviru procjene utjecaja riječnog sedimenta}

\section{1. Dizajn}

Složenost sedimentnog sustava, koja se danas prihvaća diljem svijeta nakon više od 25 godina računalnog prikupljanja podataka, pokazuje da su potrebni pouzdaniji pristupi i metodologije za potpuno definiranje tokova sedimenta i dinamike krajolika u ovisnosti o pokretačkim silama. To se također odnosi na studije za EIA-u i ESIA-u koje moraju pokazati da planirani građevinski projekti neće loše utjecati na primjerice riječne, ekološke i onečišćujuće procese - niti će na njih nepovoljno djelovati prirodne sile (poput primjerice incidenta u Fukushimi 2011.). Zato ovdje opisujemo novi okvir procjene utjecaja riječnog sedimenta (Fluvial Sediment Impact Assessmen, FSIA) (sl. 4). Njime se pokušava povezati utjecaje građevinskih projekata (npr. polaganje cjevovoda u rijeke) s procesima finih sedimenata te ekološke reakcije uz prikaz gdje se svaka nadzorna tehnika može upotrijebiti.

Kao smjernice novog okvira FSIA-e u nastavku rada uspostavlja se, uz raspravu, sljedeće:

- tri opća načela

- šest metodoloških koraka

- nekoliko tehničkih pristupa.

FSIA uključuje kombinaciju stalnog nadzora količine i kakvoće vode, skupljanje i analizu hidromorfoloških podataka te bionadzor. FSIA se može upotrijebiti kao prilagodljiv okvir utemeljen na rizicima te bi ga u idealnom slučaju trebalo primijeniti pri osmišljavanju višestrukih studija utjecaja prije i nakon nadzora (Before-After-Control-Impact, mBACI). 
Fig. $4 \mathrm{~A}$ new framework for Fluvial Sediment Impact Assessment

(FSIA).

SI. 4. Novi okvir za ocjenu utjecaja riječnog sedimenta (Fluvial Sediment Impact Assessment, FSIA)

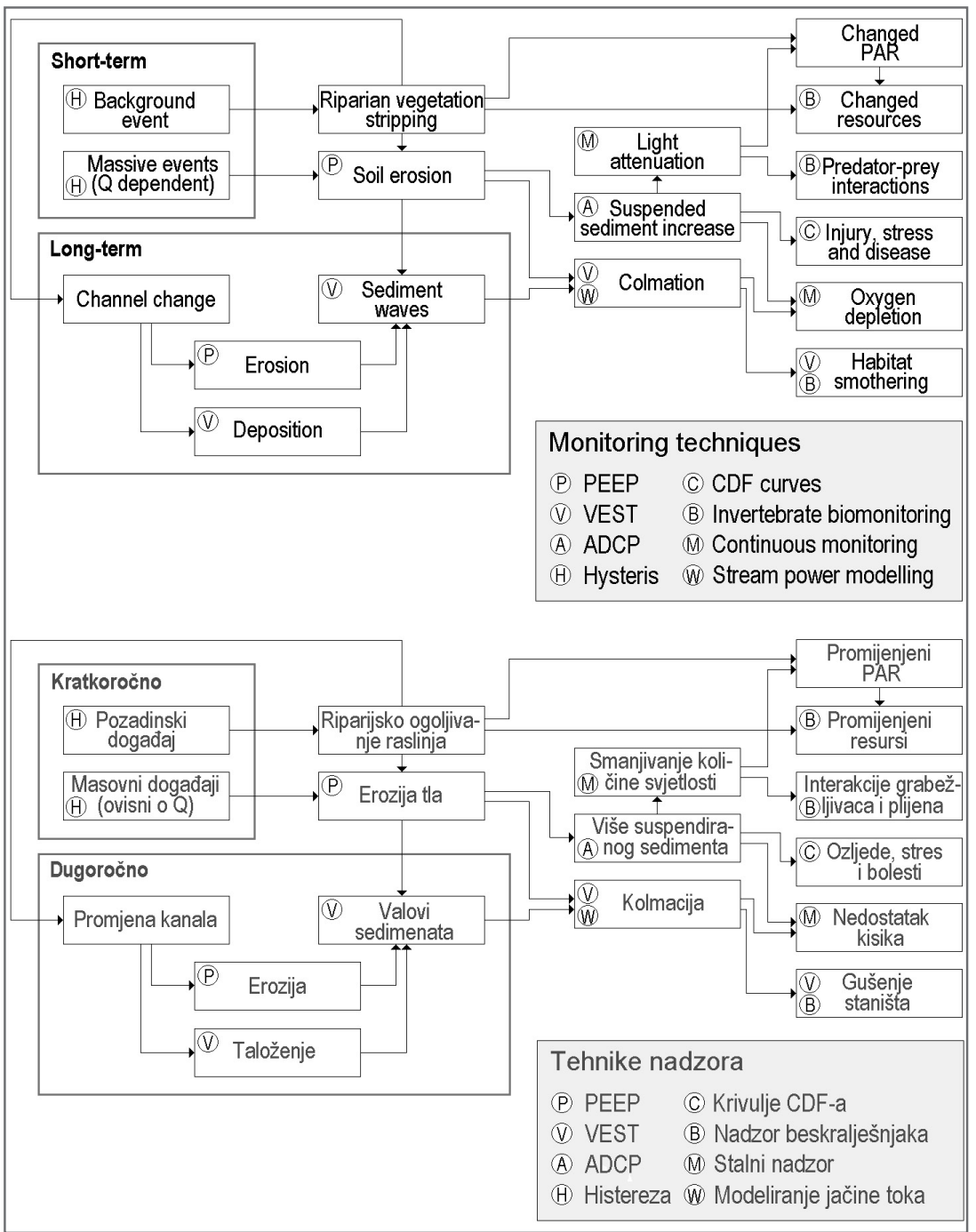

D. M. Lawler, M. A. Wilkes

Towards Improved

Fluvial Sediment

Impact Assessment

(FSIA) approaches within Environmental Impact Assessments

Novi okvir za procjenu utjecaja riječnog sedimenta u studijama utjecaja na okoliš

\subsection{Framework}

\subsubsection{Principles}

It is useful first to establish three general principles to guide Sediment Impact Assessment for project ESIAs:

1 A specialist scoping and pre-scoping at early stages of the project design, so that all key issues and key sites, including sediment issues, are integrated in the full ESIA plan

2 "Partnering" of local and international sediment/ water resource specialists to combine their experience of contrasting fluvial systems, sediment behaviour and ecological impacts

\section{2. Okvir}

\section{2. 1. Načela}

Korisno je najprije ustanoviti tri opća načela smjernica procjene utjecaja sedimenta za projektne ESIA-e:

1 Specijalističko određivanje i predodređivanje u ranim fazama osmišljavanja projekta kako bi se potpunim planom ESIA-e moglo obuhvatiti sva ključna pitanja i lokacije, uključujući i one o sedimentima

2 „Partnerstvo” s lokalnim i inozemnim stručnjacima za sedimente/vodne resurse radi povezivanja iskustava o kontrastnim riječnim sustavima, ponašanju sedimenata i ekološkom utjecaju 
3 Post-project monitoring (rarely achieved hitherto) to test earlier ESIA predictions of sediment impacts against actual sediment transport changes and impacts following project completion.

\subsubsection{Methodological steps}

The FSIA approach also incorporates the following six methodological steps. These should be implemented according to recommended scientific protocols, $\mathrm{mBACI}$ approaches and any extant legislation in the host country etc.

1 Establish, well before the development project begins, a direct, manual turbidity measurement programme. This will allow approximate baseline sediment transport estimates to be made, against which to assess any sediment impacts of the installation phase or the completed project (e.g. pipeline river crossings)

2 Manual water sampling using recognised samplers (e.g. USDH48) and filtration of river waters to obtain actual SSC for particle size distribution analysis and to calibrate turbidity meters to provide SSC data

3 Supplementary automatic monitoring - and automatic sampling - to deliver the ideal high frequency measurements of changing turbidity and SSC before, through and after storms and floods (e.g. Lawler and Brown, 1992; Lawler et al., 2006a; Old et al, 2005). This is essential to capture the full fluvial sediment transport response to catchment rainfall events and meltwater inputs to feed into hydroecological impact work - and also to detect river disturbance and elevated SSCs through the development process, such as from pipeline river crossing activities. For example, sediment transport monitoring upstream and downstream of pipeline river crossing locations, before, during and after crossing engineering can be very illuminating

4 Installing automatic river flow gauging stations at critical points on the river network, at the suspended sediment monitoring sites, if these are absent. These will provide continuous flow data to combine with SSC data (step 3) to produce suspended sediment flux estimates which are useful in
3 Poslijeprojektni nadzor (u čemu se dosad rijetko uspijevalo) kako bi se predvidanja ESIA-e o utjecajima sedimenta usporedila sa stvarnim promjenama u pronosu sedimenta nakon završetka projekta.

\section{2. 2. Metodološki koraci}

Pristup FSIA-e također obuhvaća šest navedenih metodoloških koraka. Njih valja primijeniti u skladu s preporučenim znanstvenim protokolima, pristupima $\mathrm{mBACI}$, svim postojećim propisima $\mathrm{u}$ zemlji domaćinu itd.

1 Mnogo prije početka građevinskog projekta valja uspostaviti program izravnoga ručnog mjerenja zamućenosti vodotoka. Tako će se moći ustanoviti približne temeljne procjene pronosa sedimenta s kojima će se uspoređivati utjecaj sedimenta u fazi izgradnje, odnosno završenog projekta (npr. polaganja naftovoda kroz rijeku).

2 Ručno uzimanje uzoraka vode uporabom priznatih uređaja (npr. USDH48) i filtriranje riječne vode kako bi se ustanovio stvarni SSC za analizu raspodjele veličine čestica i kalibriranje mjerača zamućenja koji daju podatke o SSC-u.

3 Dodatni automatski nadzor - i automatsko uzimanje uzoraka - kako bi se ustanovila idealna učestalost mjerenja promjene zamućenosti i SSC-a prije, tijekom i nakon oluja i poplava (Lawler i Brown, 1992; Lawler i dr., 2006a; Old i dr., 2005). To je najvažnije za bilježenje svih reakcija pronosa riječnih sedimenata poslije kiša u poriječju i dotoka otopljenog snijega kako bi se dobila potpuna slika o hidroekološkim utjecajima, ali i kako bi se zamijetile promjene u rijeci i povišen SSC tijekom građevinskog procesa, primjerice polaganja naftovoda na riječno korito. Zato nadziranje pronosa sedimenta uzvodno i nizvodno od naftovoda prije i nakon građevinskih radova može dovesti do vrijednih spoznaja.

4 Postavljanje automatskih mjernih postaja protoka na kritičnim točkama riječnog sustava i na mjestima nadzora suspendiranog sedimenta ako ih već nema. Tako će se dobiti stalni podaci o protoku koji će s podacima za SSC (korak 3) omogućiti procjene toka suspendiranog sedimenta radi 
mass-balance approaches to anticipate likely depositional rates and impacts downstream for local fisheries, ecosystems and water bodies, such as reervoirs.

5 It is very useful to identify the key sediment sources within a catchment. This can be done by chemically "matching" likely sources of fine sediment across the catchment with the suspended sediment retrieved from the manual samplers and Automatic Water Samplers, and incorporating hydrogeomorphological or tracing studies). PEEP3T deployment can also support this, by revealing timing of sediment loss from selected catchment sources with respect to SSC peaks.

6 Suitable adjustments to the above can be made for whichever water bodies are at risk or of interest (e.g. lakes, reservoirs, wetlands, soil water, groundwater systems, wells, springs and drainage systems).

\subsubsection{Incorporated techniques}

The FSIA also embraces a suite of techniques for monitoring suspended sediment pollution. Other approaches rely on detecting the impact of works such as pipeline crossings, including channel change (Castro et al., 2014) or the response of biota after the impact has occurred (Anderson et al., 1998). However, our framework recognises the need to monitor processes of sediment pollution generation and transport so that an early warning alarm can be raised before ecological status is compromised (Fig. 4). FSIA also involves the combination of key technical approaches, including monitoring of water quantity and quality, hydromorphological data collection and analysis, and biomonitoring, as discussed below.

\subsubsection{Automated high-frequency/Continuous monitoring}

The strong temporal dynamics exhibited by SSC (e.g. Fig. 2) necessitates high-frequency monitoring (e.g. Lecce et al., 2006). Due to the labour involved in collecting and processing physical samples, the most common methods involve surrogate measures of SSC using optical techniques such as turbidim- predviđanja vjerojatne brzine taloženja i utjecaja na nizvodne korisnike poput ribogojilišta, ekosustava i vodosprema.

5 Vrlo je korisno ustanoviti najvažnije izvore sedimenta u poriječju. To se kemijski može učiniti „uspoređivanjem” vjerojatnih izvora finog sedimenta u poriječju sa suspendiranim sedimentom dobivenim ručnim ili automatskim uzimanjem uzoraka riječne vode uz primjenu trasiranja i hidrogeomorfoloških metoda. Uporaba PEEP3T-a također može pomoći jer omogućuje određivanje vremena gubitka sedimenta iz odabranih izvora u poriječju s obzirom na vrhunce SSC-a.

6 Odgovarajuće se prilagodbe navedenih koraka mogu načiniti za sve zanimljive ugrožene vode (npr. jezera, vodospreme, močvare, vodu u tlu, sustave podzemnih voda, zdence, izvore i drenažne sustave).

\section{2. 3. Uključene tehnike}

FSIA također obuhvaća skup tehnika za nadzor onečišćenja suspendiranog sedimenta. Drugi se pristupi temelje na otkrivanju utjecaja građevinskih radova poput položenih cjevovoda, uključujući promjenu kanala (Castro i dr., 2014) ili reakcije živih bića nakon završetka građevinskog projekta (Anderson i dr., 1998). No naš okvir prihvaća potrebu za nadzorom procesa stvaranja i prijenosa onečišćenja sedimentom kako bi se moglo dati rano upozorenje, prije narušavanja ekološkog stanja (sl. 4). FSIA također obuhvaća kombinaciju ključnih tehničkih pristupa, uključujući nadzor količine i kakvoće vode, skupljanje i analizu hidromorfoloških podataka te bionadzor, o čemu će biti više riječi u nastavku.

\section{2. 3. 1. Automatski učestali/stalni monitoring}

Velika vremenska dinamika SSC-a (vidi sl. 2) zahtijeva veoma čest nadzor (npr. Lecce i dr., 2006). Zbog količine rada uključenog u skupljanje i obradu fizičkih uzoraka, najčešće metode uključuju nadomjesno mjerenje SSC-a optičkim tehnikama mjerenja zamućenosti, u novije doba laserskom refraktometrijom. Iako je skuplja, laserska refraktometrija mje-
D. M. Lawler, M. A. Wilkes

Towards Improved

Fluvial Sediment Impact Assessment

(FSIA) approaches within Environmental Impact Assessments

Novi okvir za procjenu utjecaja riječnog sedimenta u studijama utjecaja na okoliš 
etry or, more recently, laser refractometry. Whilst more expensive, laser refractometry using Laser In-Situ Scattering and Transmissometers (LISSTs) can provide more reliable estimates of SSC and has the added benefit of providing particle size distributions (Czuba et al., 2014). Both optical techniques ideally require site-specific calibration, preferably across a range of seasons and flow stages (Jastram et al., 2009; Andrews et al., 2011), to give a robust estimate of SSC at the sensor. In turn, SSC at the sensor should be calibrated to cross-sectional mean SSC using a depth- and width-integrating method. Optical sensors should be installed in combination with datalogging or telemetry hardware and a pressure transducer, calibrated to provide an estimate of discharge (Q). Dissolved oxygen should be monitored as standard. If there are any other specific water quality concerns then continuous monitoring systems can also be equipped with water quality sondes. Compared to the expense of a pipeline crossing the cost of these systems is not prohibitive, yet barely any projects involve collection of such data, even at a very coarse temporal resolution.

\subsubsection{Hydromorphological data collection and analysis}

The collection of hydrological and morphological data is crucial to detecting hot spots and hot moments of potential sediment processes linked to pipeline crossings, or other development activity. Acoustic Doppler Current Profilers (ADCPs) are useful as they can provide reliable depth- and width-integrated Q and SSC data simultaneously, facilitating the rapid cross-sectional calibration of point SSC data located close to optical sensors. Because ADCP is a surrogate method, the acoustic backscatter data collected still requires calibration using manual samples. Sassi et al. (2012) have shown how this can be done efficiently. The resulting $\mathrm{Q}$ and SSC data may then be used to analyse hysteretic behaviour, which can indicate the relative contributions of proximal (e.g. bank erosion, pipeline crossings) and distal sediment sources (Lawler et al., 2006a; Lefrançois et al., 2007). renjem laserskog raspršivanja i transmisije (Laser In-Situ Scattering and Transmissometer, LISST) nudi pouzdanije procjene SSC-a i ima dodatnu prednost pronalaženja raspodjele veličine čestica (Czuba i dr., 2014). Obje optičke tehnike u idealnom slučaju zahtijevaju kalibraciju na mjestu uporabe, tijekom nekoliko godišnjih doba i različitih protoka ako je to moguce (Jastram i dr., 2009; Andrews i dr., 2011) kako bi se senzorom dobile pouzdane procjene SSC-a. S druge strane, SSC na senzoru valja kalibrirati na srednju vrijednost presjeka korita dubinskim i širinskim postupcima integracije. Optičke senzore treba postaviti u kombinaciji s opremom za bilježenje podataka ili telemetriju, a mora biti prisutan i tlačni pretvarač (transduktor) kalibriran da ponudi procjenu pražnjenja (Q). Standardno valja mjeriti i količinu otopljenoga kisika. Postoje li bilo kakve sumnje u kakvoću vode, sustavi za stalni nadzor moraju biti opremljeni i sondama za određivanje kakvoće vode. U usporedbi s cijenom polaganja naftovoda preko riječnog dna cijena tih sustava nije previsoka, ali gotovo da i nema projekta koji uključuje prikupljanje takvih podataka, čak ni u vrlo velikim vremenskim razmacima.

\section{2. 3. 2. Prikupljanje i analiza hidromorfoloških podataka}

Prikupljanje hidroloških i morfoloških podataka najvažnije je za pronalaženje vrućih točaka i vrućih trenutaka potencijalnih sedimentacijskih procesa povezanih s polaganjem cjevovoda ili drugih građevinskih aktivnosti. Akustički uređaji za doplersko profiliranje toka (Acoustic Doppler Current Profilers, ADCP) korisni su jer istodobno nude pouzdane dubinski i širinski integrirane podatke za Q i SSC pa se tako olakšava brza kalibracija po presjeku diskretnih podataka o SSC-u blizu optičkih senzora. Kako je ADCP nadomjesna metoda, prikupljeni akustički podaci o raspršivanju moraju se kalibrirati s pomoću uzoraka dobivenih ručno. Sassi i dr. (2012) pokazali su da se to može učiniti učinkovito. Dobiveni podaci o Q-u i SSC-u mogu se zatim upotrijebiti za analizu ponašanja histereze, koja može uputiti na relativne doprinose bliskih (npr. erozija obale, položeni cjevovodi) i udaljenih izvora sedimenta (Lawler i dr., 2006a; Lefrançois i dr., 2007). 
Photo-Electronic Erosion Pins (PEEP) or the newer version (PEEP3T) can provide detailed information on catchment erosion dynamics, and process behaviour and sediment generation at specific erosion sites (e.g. river banks, agricultural fields, cleared areas, or pipeline river crossing sites) (e.g. Fig. 5) and their role in sediment fluxes (Lawler, 2005b; 2008). Identifying key sources of potential ecological impacts associated with pipeline crossings in both the short- and long-term is key. Much eroded material may accumulate on and within the river bed matrix. Vertically Extending Sediment Traps (VESTs) can enable the rate of colmation to be quantified with unprecedented realism by allowing free movement of fine sediment both from the bed surface and laterally within the bed matrix (Harper et al., in submission). As the sensitivity of river habitats to deposition and erosion is dependent on local and upstream stream power distributions (Barker et al.,2009; Bizzi and Lerner, 2012, 2015), spatial models that rapidly map stream power along whole rivers using existing topographical and hydrological data based on Digital Elevation Models and Geographical Information Systems (Barker et al., 2009) are important for identifying vulnerable sites for more detailed investigations.
Fotoelektronički erozijski klinovi (Photo-Electronic Erosion Pins, PEEP) ili novije inačice (PEEP3T) mogu dati detaljne informacije o dinamici erozije u poriječju, ali i procesima i i nastanku sedimenta na određenim mjestima erozije (npr. riječne obale, poljoprivredne površine, iskrčena područja ili mjesta prelaska cjevovoda kroz riječni tok) (sl. 5) te njihovoj ulozi u toku sedimenta (Lawler, 2005b, 2008). I kratkoročno i dugoročno najvažnije je prepoznavanje glavnih izvora potencijalnih ekoloških utjecaja povezanih s položenim cjevovodima. Mnogo se erodiranog materijala može nakupiti na osnovici riječnoga korita i u njoj. Omogućujući slobodno kretanje finog sedimenta iz površine korita i lateralno unutar osnove korita, vertikalne sedimentne zamke (Vertically Extending Sediment Traps, VEST) omogućuju kvantificiranje kolmacije s dosad nedosegnutom točnošću (Harper i dr., u tisku). Kako je osjetljivost riječnih staništa na taloženje i eroziju ovisna o lokalnoj i uzvodnoj raspodjeli jačine vodene struje (Barker i dr., 2009; Bizzi i Lerner, 2012, 2015), prostorni modeli za brzo određivanje jačine struje uzduž cijelih rijeka uporabom postojećih topografskih i hidroloških podataka utemeljenih na digitalnim modelima reljefa i geografskim informacijskim sustavima (Barker i dr., 2009) vrlo su važni za pronalaženje osjetljivih lokacija koje valja podrobnije istražiti.
D. M. Lawler, M. A. Wilkes

Towards Improved

Fluvial Sediment

Impact Assessment

(FSIA) approaches within Environmental Impact Assessments

Novi okvir za procjenu utjecaja riječnog sedimenta u studijama utjecaja na okoliš
Fig. 5 Pipeline laid directly within a highly turbid mountain river in eastern Azerbaijan. Clearly, a pipeline failure or breach, including by gravel or boulder impact erosional undermining of pipeline river crossing footings, accidental disturbance during subsequesmt engineering works, sabotage or vandalism (Anifowose et al., 2011: 2012; 2014), can lead to substantial spills of oil or other contents into river systems and contaminate water and sediments.

SI. 5. Naftovod položen izravno u vrlo zamućenu planinsku rijeku na istoku Azerbajdžana. Očito je da kvar ili pucanje cijevi uzrokovano primjerice udarom śljunka ili stijene, eroziiskim potkopavaniem nosača cijevi, nehotičnim pomicanjem tijekom mogućih građevinskih radova, sabotažom ili vandalizmom (Anifowose idr. 2011. 2012, 2014) mogu uzrokovati veliko izlijevanje nafte ili drugog sadržaja u riječni sustav te tako onečistiti vodu i sedimente.

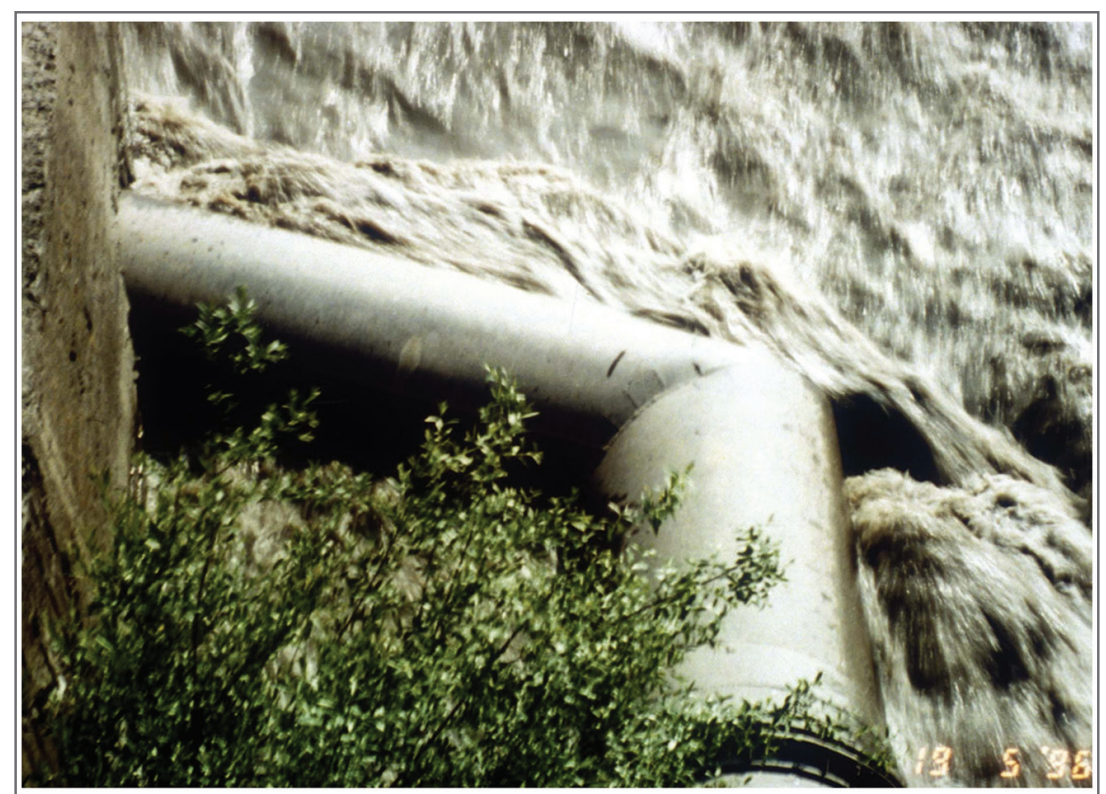




\subsubsection{Biomonitoring}

Biomonitoring may be used to detect a wide variety of impacts, such as organic pollution (Wright et al., 1989), heavy metal contamination (Blanco \&Bécares, 2010) and flow abstraction (Extence et al., 1999). Aquatic macroinvertebrates are most often used for biomonitoring as they are easy to sample, relatively sedentary, ubiquitously distributed, have short life-cycles and high sensitivity to environmental change (Giller and Malmqvist, 1998). In recognition of the widespread nature of fine sediment pollution, Extence et al. (2013) developed the Proportion of Sediment-sensitive Invertebrates (PSI) index (Tab. 1). The PSI index has been found to be sensitive to sediment pollution from a range of sources (Poole et al., 2013; Glendell et al., 2014; Turley et al., 2014; see example below). The effects of changed resources and altered predator-prey interactions can also be tracked by sampling macroinvertebrates and assigning each family or species to groups according to feeding habits and other traits (Schmidt-Kloiber et al., 2006).

\section{2. 3. 3. Bionadzor}

Bionadzorom se mogu otkriti različite vrste utjecaja, primjerice organskog onečišćenja (Wright i dr., 1989), kontaminacije teškim metalima (Blanco i Bécares, 2010) te crpljenja vode (Extence i dr., 1999). $\mathrm{Za}$ bionadzor najviše se upotrebljavaju vodeni makrobeskralješnjaci jer ih je lako skupljati, razmjerno su nepokretni, posvuda rašireni, imaju kratke životne cikluse i iznimno su osjetljivi na promjene u okolišu (Giller i Malmqvist, 1998). Prepoznajući raširenost onečišćenja finim sedimentima, Extence i dr. (2013) osmislili su indeks dijela beskralješnjaka osjetlivin na sediment (Proportion of Sediment-sensitive Invertebrates, PSI) (tab. 1). Indeks PSI pokazao se osjetljivim na onečišćenje sedimentima iz različitih izvora (Poole i dr., 2013; Glendell i dr., 2014; Turley i dr., 2014; vidi primjer u nastavku). Učinci promijenjenih resursa i promijenjenih interakcija među lovcima i plijenom također se mogu pratiti uzimanjem uzoraka makrobeskralješnjaka i svrstavajući svaku porodicu ili vrstu u skupine u skladu s prehrambenim navikama i drugim obilježjima (Schmidt-Kloiber i dr., 2006).

Tab. 1 Fine Sediment Sensitivity Rating definitions and abundance weighted scores for PSI calculation. See Extenceet al. (2013) for species-and family-level FSSR designations.

Tab. 1. Definicije i rezultati ponderirani prema pojavnosti za ocjenu osjetljivosti na fine sedimente u izračunu PSl; vidi Extence i dr. (2013) za FFSR oznake razine vrsta i porodica

\begin{tabular}{|c|c|c|c|c|c|}
\hline \multirow{2}{*}{ Group } & \multirow{2}{*}{ Fine Sediment Sensitivity Rating (FSSR) } & \multicolumn{4}{|c|}{ Abundance } \\
\hline & & 1-9 & 10-99 & 100-999 & $1000+$ \\
\hline \multirow{2}{*}{ Skupina } & \multirow{2}{*}{$\begin{array}{l}\text { Ocjena osjetljivosti na fini sediment } \\
\text { (Fine Sediment Sensitivity Rating, FSSR) }\end{array}$} & \multicolumn{4}{|c|}{ Pojavnost } \\
\hline & & 1-9 & $10-99$ & 100-999 & $1000+$ \\
\hline A & Highly sensitive / Vrlo osjetljiva & 2 & 3 & 4 & 5 \\
\hline B & Moderately sensitive / Srednje osjetljiva & 1 & 2 & 3 & 4 \\
\hline $\mathrm{C}$ & Moderately insensitive / Srednje neosjetljiva & 1 & 2 & 3 & 4 \\
\hline $\mathrm{D}$ & Highly insensitive / Vrlo neosjetljiva & 2 & 3 & 4 & 5 \\
\hline
\end{tabular}

$$
\operatorname{PSI}(\Psi)=\frac{\sum \text { Scores_Groups_A\& } B}{\sum \text { Score_Groups_A, } B, C \& D} x 100
$$


To test this, we monitored sediment pollution from a flood alleviation scheme in Chipping Campden, Gloucestershire, UK. A $400 \mathrm{~m}$ length of the second-order stream was diverted away from the premises of a local business that had been experiencing unacceptable levels of flooding. Construction of the new channel involved excavating alluvium from the valley bottom and reconnecting this new section of channel to the existing stream. Monitoring was conducted by sampling macroinvertebrate communities at three replicate sites upstream (control) and immediately downstream (impact) of the site. A key result is that the PSI scores were significantly lower at the impacted site downstream of the works until recovery is seen after 25 weeks when the bed and banks of the new channel had become vegetated, limiting sediment erosion (Fig. 6).
Kako bismo to iskušali, nadzirali smo onečiščenje sedimentom u projektu saniranja štete od poplave u Chipping Campdenu u Gloucestershireu u Ujedinjenom Kraljevstvu. Potok duljine 400 m preusmjeren je s terena lokalnih poduzeća suočenih s učestalim poplavljivanjem. Izgradnja novoga kanala obuhvaćala je iskapanje taloga s dna doline i spajanje tog novog dijela kanala s postojećim potokom. Nadzor je izveden uzimanjem uzoraka zajednica makrobeskralješnjaka na tri različita mjesta uzvodno (kontrolni uzorci) i neposredno nizvodno (pod utjecajem promjene) od lokaliteta. Najvažniji rezultat bio je da su ocjene PSI-ja bile znatno niže na zahvaćenome mjestu nizvodno od radova sve dok nakon 25 tjedana nije nastupio oporavak kad se na koritu i obali novoga kanala pojavilo raslinje koje je ograničilo eroziju sedimenta (sl. 6).
D. M. Lawler, M. A. Wilkes

Towards Improved

Fluvial Sediment

Impact Assessment

(FSIA) approaches within Environmental Impact Assessments

Novi okvir za procjenu utjecaja riječnog sedimenta u studijama utjecaja na okoliš
For fish, which are more difficult to sample, more mobile and longer-lived than macroinvertebrates, direct biomonitoring is less feasible. Beyond specialist physiological bioassays (e.g. Reid et al., 2003), the use of fish population estimates to monitor sediment pollution impacts is flawed from a management perspective - the impact has already
Za ribe, koje je teže uhvatiti, pokretljivije su i žive duže od makrobeskralješnjaka, izravni bionadzor manje je prikladan. Osim u specijalističkim fiziološkim bioistraživanjima (npr. Reid i dr., 2003) riblja populacija za nadzor posljedica onečišćenja sedimentom nije opravdana s upravljačkog motrišta jer su posljedice već prisutne i malo je razloga za 
occurred and there is little basis for detecting the mechanisms involved. An alternative, cheaper and less specialist approach to fish biomonitoring uses continuous monitoring data alongside a well-established model describing the severity of ill effects suffered by fish in response to sediment pollution (Tab. 2). CDF curves can then be derived from the continuous monitoring data by applying thresholds relating to different SEV levels (e.g. Schwartz et al., 2008). In this way monitoring can rapidly alert managers to unacceptable levels of impact before fish populations are irreparably affected. otkrivanje uključenih mehanizama. Kao alternativa, jeftiniji i manje specijalistički pristup nadzoru riba upotrebljava podatke dobivene stalnim nadzorom uz široko prihvaćeni model koji opisuje ozbiljnost loših posljedica na ribe kao reakcije na onečišćenje sedimentom (tab. 2). Krivulje CDF-a tada se mogu izračunati iz stalnih podataka dobivenih nadzorom, uz primjenu granica koje se odnose na različite razine SEV-a (Schwartz i dr., 2008). Tako se nadzorom upravljačke strukture mogu brzo upozoriti na neprihvatljive razine onečišćenja prije nego što se riblja populacija nepopravljivo naruši.

Tab. 2 Scale of severity (SEV) of ill effects associated with excess suspended sediment. From Newcombe and Jensen (1996).

Tab. 2. Ljestvica ozbiljnosti (scale of severity, SEV) loših učinaka povezanih s viškom suspendiranog sedimenta; prema Newcombeu i Jensenu (1996)

\begin{tabular}{|c|c|}
\hline $\begin{array}{l}\text { SEV / } \\
\text { SEV }\end{array}$ & Description of effect / Opis učinka \\
\hline 0 & Nil effect / Nema učinka \\
\hline 1 & Alarm reaction / Uzbunjujuća reakcija \\
\hline 2 & Abandonment of cover / Napuštanje zaklona \\
\hline 3 & Avoidance response / Reakcija izbjegavanja \\
\hline 4 & $\begin{array}{l}\text { Short-term reduction in feeding rate and success / } \\
\text { Kratkoročno smanjenje učestalosti i uspjeha hranjenja }\end{array}$ \\
\hline 5 & $\begin{array}{l}\text { Minor physiological stress (coughing, increased respiration) / } \\
\text { Manji fiziološki stres (kašljanje, ubrzano disanje) }\end{array}$ \\
\hline 6 & Moderate physiological stress / Srednji fiziološki stres \\
\hline 7 & $\begin{array}{l}\text { Moderate habitat degradation; impaired homing / } \\
\text { Umjerena degradacija staništa; nemogućnost pronalaženja doma }\end{array}$ \\
\hline 8 & $\begin{array}{l}\text { Indications of major physiological stress; long-term reduction in } \\
\text { feeding rate and success; poor condition / Pokazatelji velikoga fiziološkog stresa; } \\
\text { dugoročno smanjenje učestalosti i uspjeha hranjenja; loše tjelesno stanje }\end{array}$ \\
\hline 9 & $\begin{array}{l}\text { Reduced growth rate; delayed hatching; reduced fish density / } \\
\text { Usporen rast; odgođeno mriješćenje; smanjen broj riba }\end{array}$ \\
\hline 10 & $\begin{array}{l}\text { 0-20 \% mortality; increased predation; moderate to severe habitat degradation / } \\
\text { Smrtnost od } 0 \text { do } 20 \text { posto; povećana predacija; umjerena do velika degradacija staništa }\end{array}$ \\
\hline 11 & $20-40 \%$ mortality / Smrtnost od 20 do 40 posto \\
\hline 12 & $40-60 \%$ mortality / Smrtnost od 40 do 60 posto \\
\hline 13 & $60-80 \%$ mortality / Smrtnost od 60 do 80 posto \\
\hline 14 & $80-100 \%$ mortality / Smrtnost od 80 do 100 posto \\
\hline
\end{tabular}




\section{Conclusions}

The new datasets presented here on the dynamics and complexities of bank erosion, fine sediment transport and biotic response at different timescales help to inform the development of a new approach to the evaluation of sediment impacts on river biota. The new FSIA framework we outline here is designed to anticipate and address sediment pollution problems in rivers from a process perspective, especially with respect to aquatic biota which may result from development projects. To develop the new framework, we have established three desirable general principles, six methodological steps, and several technical approaches which underpin the approach. High-frequency monitoring of both river flow and turbidity/SSC is seen to be essential before, during and after project construction (e.g. for pipeline river crossings) in order to detect and mitigate undesirable levels of sediment pollution and their impacts on ecosystems. Ideally, the approaches should be applied in a multiple Before-After-Control-Impact (mBACI) study design.

Advantages of the FSIA framework are that:

- It is process-based within hydrology, geomorphology and hydroecology, enabling the early detection of sediment impacts

- It explicitly recognises the strong temporal dynamics exhibited by SSC, and their controls

- It includes explicit reference to ecological receptors

- It capitalises on well established biomonitoring protocols where direct monitoring is challenging

- It is operational and practical rather than simply organisational or conceptual in nature

- It encourages multi- and inter-disciplinary involvement

- It is based on substantial experience of assessing impacts of major development projects on river systems in the UK, Iceland, Azerbaijan, Georgia and Russia, where components of the approach have been tested, including within Environmental and Social Impact Assessments.

The new framework here suggests that there is significant potential for more rigorous assessment of fluvial sediment conditions, before, during and

\section{Zaključci}

Ovdje predstavljeni novi skupovi podataka o dinamici i složenosti erozije obale, prijenosa finog sedimenta i reakcije živih bića u različitim vremenskim rasponima pomažu informiranju o razvoju novog pristupa procjeni utjecaja sedimenta na živi svijet $u$ rijeci. Novi okvir FSIA-e koji ovdje opisujemo namijenjen je predviđanju problema onečišćenja sedimentom u rijekama (kao posljedice građevinskih projekata) s procesnog motrišta i suočavanju s njim, osobito kad je riječ o živome svijetu u vodi.. Kako bismo razvili novi okvir, ustanovili smo tri poželjna opća načela, šest metodoloških koraka i nekoliko tehničkih pristupa na kojima se pristup temelji. Prije, tijekom i nakon projekta (primjerice polaganja cjevovoda preko riječnog dna) visokofrekventni se nadzor riječnog toka i zamućenosti/SSC-a pokazuju najvažnijim za otkrivanje i uklanjanje nepoželjnih razina onečišćenja sedimentom i njegova utjecaja na ekosustave. $U$ idealnom slučaju pristup valja primijeniti osmišljavanjem višestrukih studija utjecaja prije i nakon nadzora (Before-After-Control-Impact, mBACI).

Prednosti okvira FSIA-e jesu:

- temelji se na hidrološkim, geomorfološkim i hidroekološkim procesima, pa omogućuje rano otkrivanje utjecaja sedimenta

- izričito prihvaća veliku vremensku dinamiku specifičnu za SSC i njegov nadzor

- uključuje eksplicitne referencije na ekološke receptore

- slijedi općeprihvaćene protokole bionadzora kada je izravni nadzor otežan

- djelatan je i praktičan, a ne samo jednostavan organizacijski ili koncepcijski

- potiče multidisciplinarnost i međudisciplinarnost

- utemeljen je na velikom iskustvu procjene utjecaja opsežnih građevinskih projekata na riječnim sustavima u Ujedinjenom Kraljevstvu, Islandu, Azerbajdžanu, Gruziji i Rusiji, gdje su ispitani dijelovi pristupa, među njima i oni za procjene utjecaja na okoliš i društvo (ESIA).

Opisani novi okvir nameće zaključak da postoji znatan potencijal za kvalitetniju i strožu procjenu stanja riječnog sedimenta prije, tijekom i nakon
D. M. Lawler,

M. A. Wilkes

Towards Improved

Fluvial Sediment

Impact Assessment

(FSIA) approaches within Environmental Impact

Assessments

Novi okvir za procjenu utjecaja riječnog sedimenta u studijama utjecaja na okoliš 
HRVATSKI

GEOGRAFSKI

GLASNIK

77/2, 7-31 (2015.)

Napomena

\section{Acknowledgement}

Zahvala

Literature

Literatura after development activity, such as oil and gas pipeline crossings.

It is hoped that this initial FSIA framework will stimulate a wider debate on the future of EIA, ESIA, and SEA activities among water resource scientists, other environmental specialists, EIA practitioners, environmental consultancies, energy companies, policy makers, legal teams and local communities. The FSIA protocol is likely to be applicable to many other environments, development projects and systems, in addition to water systems. The active involvement of geographers, geomorphologists, hydrologists, ecologists and environmental scientists internationally would help to develop FSIA and its contribution to ESIA policy.

Professional Terms Editing: Ivan Čanjevac, $\mathrm{PhD}$

Translation: Ruđer Jeny

We acknowledge the help of the Environment Agency of England and Wales in providing datasets and the help of numerous international EIA and Environmental and Social Impact Assessment teams, and local scientists. građevinske aktivnosti, primjerice polaganja plinovoda i naftovoda na dno rijeke.

Nadamo se da će taj početni okvir FSIA-e među znanstvenicima koji se bave vodnim resursima, drugim ekološkim specijalistima, izvođačima EIA-e, ekološkim konzultantima, energetskim tvrtkama, političarima, pravnim timovima i u lokalnim zajednicama potaknuti širu raspravu o budućim aktivnostima EIA-a, ESAI-ja i SEA-e. Protokol FSIA može se osim za vodne sustave vjerojatno primijeniti u brojnim drugim područjima, građevinskim projektima i sustavima. Aktivno uključivanje geografa, geomorfologa, hidrologa, ekologa i ekoloških znanstvenika diljem svijeta pomoći će razvoju FSIA-e i njezinu doprinosu politici ESIA-e.

Stručna redaktura: dr. sc. Ivan Čanjevac

Prijevod: Ruđer Jeny

Zahvaljujemo na podacima Agenciji za okoliš Engleske i Walesa te pomoći brojnih timova EIA-e i ESIA-e i lokalnih znanstvenika.
Alonso, C. V., Theurer, F. D., Zachmann, D. W., 1996: Sediment intrusion and dissolved oxygen transport model-SIDO. Technical Report 5, United States Department of Agriculture.

Anifowose, B. A., Chapman, L. C., Lawler, D. M. and van der Horst, D. 2011. Pipeline interdiction and bridging in Nigeria: is a modification to the spatial connectivity matrix model required? Journal of Transport Geography 19 (1), 179-184.

Anifowose, B. A., Lawler, D. M., van der Horst, D. and Chapman, L. C. 2012. Attacks on oil transport pipelines in Nigeria: a quantitative exploration and possible explanation of observed patterns. Applied Geography 32, 636-651.

Anifowose, B. A., Lawler, D. M., van der Horst, D. and Chapman, L. C. 2014 Evaluating interdiction of oil pipelines at river crossings using Environmental
Impact Assessments, Area: Journal of the Royal Geographical Society, 46.1, pp.4-17, doi: 10.1111/area.12065

Anderson, P. G, Fraikin, C. G. J., Chandler, T. J., 1998: Impacts and recovery in a coldwater stream following a natural gas pipeline crossing installation. Proceedings of the International Pipeline Conference (vol. 2), American Society of Mechanical Engineers, Calgary, Alberta, 1013-1020.

Andrews, S. W., Nover, D. M., Reardon, K. E., Reuter, J. E., Schladow, S. G., 2011: The influence of ambient light intensity on in situ laser diffractometers. Water Resources Research 47 (6), W06509.

Barker, D. M., Lawler, D. M., Knight, D. W., Morris, D. G., Davies, H. N., Stewart, E. J., 2009: Longitudinal distributions of river flood power: the combined automated flood, elevation and stream power (CAFES) methodology. Earth Surface Processes and Landforms 34 (2), 280-290.

Bilotta, G. S., Brazier, R. E., 2008: Understanding the Influence of suspended solids on water quality and aquatic biota. Water Research 42 (12), 2849-2861.

Bilotta, G. S., Burnside, N. G., Cheek, L., Dunbar, M. J., Grove, M. K., Harrison, C., Davy-Bowker, J., 2012: Developing environment-specific water quality guidelines for suspended particulate matter. Water Research 46 (7), 23242332.

Bizzi, S., Lerner, D. N., 2012: Characterizing physical habitats in rivers using map-derived drivers of fluvial geomorphic processes. Geomorphology 169, 6473.

Bizzi, S., Lerner, D. N., 2015: The use of stream power as an indicator of chan- 
nel sensitivity to erosion and deposition processes. River Research and Applications 31, 16-27.

Blanco, S., Bécares, E., 2010: Are biotic indices sensitive to river toxicants? A comparison of metrics based on diatoms and macro-invertebrates. Chemosphere 79 (1), 18-25.

Boano, F., Harvey, J. W., Marion, A., Packman, A. I., Revelli, R., Ridolfi, L., Wörman, A., 2014: Hyporheic flow and transport processes: Mechanisms, models, and biogeochemical implications. Reviews of Geophysics 52 (4), 603-679.

Castro, J. M., MacDonald, A., Lynch, E., Thorne, C. R. (2014). Risk-based Approach to Designing and Reviewing Pipeline Stream Crossings to Minimize Impacts to Aquatic Habitats and Species.River Research and Applications DOI: $10.1002 / \mathrm{rra} .2770$.

Collins, A. L., Walling, D. E., Webb, L., King, P., 2010: Apportioning catchment scale sediment sources using a modified composite fingerprinting technique incorporating property weightings and prior information. Geoderma 155 (3), 249-261.

Collins, A. L., Williams, L. J., Zhang, Y. S., Marius, M., Dungait, J. A. J., Smallman, D. J., Dixon, E. R., Stringefellow, A., Sear, D. A., Jones, J. I., Naden, P. S., 2013: Catchment source contributions to the sediment-bound organic matter degrading salmonid spawning gravels in a lowland river, southern England. Science of the Total Environment 456, 181-195.

Czuba, J. A., Straub, T. D., Curran, C. A., Landers, M. N., Domanski, M. M., 2015: Comparison of fluvial suspended-sediment concentrations and particle-size distributions measured with in-stream laser diffraction and in physical samples. Water Resources Research 51, DOI: 10.1002/2014WR015697.

Extence, C. A., Balbi, D. M., Chadd, R. P., 1999: River flow indexing using British benthic macroinvertebrates: a framework for setting hydroecological objectives. Regulated Rivers Research E Management (15), 545-574.

Extence, C. P., Chadd, R., England, J. J., Dunbar, M. J., Wood, P. D., Taylor, E., 2013: The Assessment Of Fine Sediment Accumulation In Rivers Using Macro-Invertebrate Community Response. River Research and Applications
29 (1), 17-55.

Giller, P. S., Malmqvist, B., 1998: The Biology of Streams and Rivers. Oxford University Press, Oxford, UK.

Glendell, M., Extence, C., Chadd, R., Brazier, R. E., 2014: Testing the pressure-specific invertebrate index (PSI) as a tool for determining ecologically relevant targets for reducing sedimentation in streams. Freshwater Biology 59 (2), 353-367.

Graham, A. A., 1990: Siltation of stone-surface periphyton in rivers by clay-sized particles from low concentrations in suspention. Hydrobiologia 199 (2), 107-115.

Gray, J. R., Gartner, J. W., 2009: Technological Advances in Suspended-sediment Surrogate Monitoring. Water Resources Research 45 (4), DOI: 10.1029/2008WR007063.

Greig, S. M., Sear, D. A., Smallman, D., Carling, P. A., 2005: Impact of clay particles on the cutaneous exchange of oxygen across the chorion of Atlantic salmon eggs. Journal of Fish Biology 66 (6), 1681-1691.

Greig, S. M., Sear, D. A., Carling, P. A., 2007: A review of factors influencing the availability of dissolved oxygen to incubating salmonid embryos. Hydrological Processes 21 (3), 323-334.

Grove, M. K., Bilotta, G. S., Woockman, R. R., Schwartz, J. S., 2015: Suspended sediment regimes in contrasting reference-condition freshwater ecosystems: Implications for water quality guidelines and management. Science of the Total Environment 502, 481-492.

Harper, S., Foster, I., Lawler, D. M., in review: Accumulation of fine sediments within channel-bed gravels of urban rivers: a comparison of two sampling techniques. Hydrological Processes.

Jastram, J. D., Moyer, D. L., Hyer, K. E., 2009: A comparison of turbidity-based and streamflow-based estimates of suspended-sediment concentrations in three Chesapeake Bay tributaries. US Department, of the Interior, US Geological Survey.

Jones, J., Collins, A., Naden, P., Sear, D., 2012a: The Relationship between Fine Sediment and Macrophytes in Rivers. River Research and Applications 28 (7) 1006-1018.

Jones, J., Murphy, J., Collins, A., Sear, D.
Naden, P., Armitage, P. 2012b: The Impact of Fine Sediment on Macro-Invertebrates. River Research and Applications 28 (8), 1055-1071.

Julian, J. P., Doyle, M. W., Stanley, E. H. 2008: Empirical modeling of light availability in rivers. Journal of Geophysical Research: Biogeosciences (2005-2012), 113 (G3).

Lawler, D. M., 1992: Design and installation of a novel automatic erosion monitoring system. Earth Surface Processes and Landforms 17 (5), 455-463.

Lawler, D. M., Sljivic, S. and Caplat, M. 1996. Assessing the environmental impact of the Birmingham Airport Link pipeline, In: Gerrard, A. J. G. and Slater, T. R. S. (Eds) Managing a Conurbation: Birmingham and its Region, British Association for the Advancement of Science, Brewin, 75-89.

Lawler, D. M. 2004. Safeguarding water resources in the Former Soviet Union in an era of transition: establishing Water Impact Assessment with the EIA process, European Water, 3/4, 28-35.

Lawler, D. M. 2005a. Towards the implementation of Strategic Environmental Assessment (SEA): learning from EIA for water resources, In: Schmidt, M., Joao, E. and Albrecht, E. (Eds) Implementing Strategic Environmental Assessment, Springer-Verlag, 495-511.

Lawler, D. M., 2005b: Spectrophotometry: Turbidimetry and Nephelometry', in Encyclopedia of Analytical Science ( ${ }^{\text {nd }} \mathrm{ed}$.). Elsevier, Amsterdam, 343-351.

Lawler, D. M., 2005c: The importance of high-resolution monitoring in erosion and deposition dynamics studies: examples from estuarine and fluvial systems. Geomorphology 64 (1), 1-23.

Lawler, D. M., 2008: Advances in the continuous monitoring of erosion and deposition dynamics: Developments and applications of the new PEEP-3T system. Geomorphology 93 (1), 17-39.

Lawler, D. M. 2015 In press: “Turbidity, Turbidimetry and Nephelometry”, Encyclopaedia of Analytical Science, 3rd edition; Elsevier, 12pp.

Lawler, D. M., Brown, R. M., 1992: A simple and inexpensive turbidity meter for the estimation of suspended sediment concentrations. Hydrological Processes 6 ( 2), 159-168.
D. M. Lawler,

M. A. Wilkes

Towards Improved

Fluvial Sediment

Impact Assessment

(FSIA) approaches within Environmental Impact

Assessments

Novi okvir za procjenu utjecaja riječnog sedimenta u studijama utjecaja na okoliš 
GEOGRAFSKI

GLASNIK

77/2,7-31 (2015.)
Lawler, D. M., Petts, G. E., Foster, I. D., Harper, S., 2006a: Turbidity dynamics during spring storm events in an urban headwater river system: The Upper Tame, West Midlands, UK. Science of the Total Environment 360 (1), 109-126.

Lawler, D. M., Foster, I. D., Petts, G. E., Harper, S., Morrissey, I. P., 2006b: Suspended sediment dynamics for June storm events in the urbanized River Tame, UK. IAHS Publication 306, 96.

Lawler, D. M., Old, G. H., Sear, D. A. and Cardenas, B. 2009: Geomorphology and Sediments of the Hyporheic Zone, In: The Hyporbeic Handbook: A Handbook on the Groundwater-Surface Water Interface and Hyporheic Zone for Environment Managers, Environment Agency Integrated Catchment Science Programme, Science report: SC050070, Chapter 3, pp.16-47.

Lecce, S. A., Pease, P. P., Gares, P. A., Wang, J., 2006: Seasonal controls on sediment delivery in a small coastal plain watershed, North Carolina, USA. Geomorphology 73 (3), 246-260.

Lefrançois, J., Grimaldi, C., GascuelOdoux, C., Gilliet, N., 2007: Suspended sediment and discharge relationships to identify bank degradation as a main sediment source on small agricultural catchments. Hydrological Processes 21 (21), 2923-2933.

Lévesque, L. M., Dubé, M. G., 2007: Review of the effects of in-stream pipeline crossing construction on aquatic ecosystems and examination of Canadian methodologies for impact assessment. Environmental monitoring and assessment 132 (1-3), 395-409.

Massoudieh, A., Gellis, A., Banks, W. S. Wieczorek, M. E., 2013: Suspended sediment source apportionment in Chesapeake Bay watershed using Bayesian chemical mass balance receptor modeling. Hydrological Processes 27 (24), 3363-3374.

Meybeck, M., Lestel, L., Bonte, P., Moilleron, R., Colin, J. L., Rousselot, O., Herve, D., de Ponteves, C., Grosbois, C., Thevenot, D. R., 2007: Historical Perspective of Heavy Metals Contamination $(\mathrm{Cd}, \mathrm{Cr}, \mathrm{Cu}, \mathrm{Hg}, \mathrm{Pb}, \mathrm{Zn})$ in the Seine River Basin (France) Following a DPSIR Approach (1950-2005). Science of the Total Environment 375 (1-3), 204231.

Mitchell, S. B., Couperthwaite, J. S., West,
J. R., Lawler, D. M., 2003: Measuring sediment exchange rates on an intertidal bank at Blacktoft, Humber Estuary, UK. Science of the Total Environment 314, 535-549.

Newcombe, C. P., Jensen, J. O., 1996: Channel suspended sediment and fisheries: a synthesis for quantitative assessment of risk and impact. North American Journal of Fisheries Management 16 (4), 693-727.

Old, G. H., Lawler, D. M., Snorrason, Á., 2005: Discharge and suspended sediment dynamics during two jökulhlaups in the Skaftá river, Iceland. Earth Surface Processes and Landforms 30 (11), 14411460.

Poole, A. E., Bradley, D., Salazar, R., Macdonald, D. W., 2013: Optimizing agri-environment schemes to improve river health and conservation value. $A g-$ riculture, Ecosystems and Environment $181,157-168$

Reid, S. M., Isaac, G., Metikosh, S., Evans, J., 2003: Physiological response of rainbow trout to sediment released during open-cut pipeline water crossing construction. Water Quality Research Journal of Canada 38 (3), 473-481.

Reid, S. M., Metikosh, M., Evans, J., 2008: Overview of River and Stream Crossings study, in: 8th International Symposium on Environmental Concerns in Rightsof-Way Management, 711-722.

Rymszewicz, A., Mockler, E., O'Sullivan, J., Bruen, M., Turner, J., Conroy, E., Kelly-Quinn, M., Harrington, J. and, Lawler, D.M. 2014. Assessing the Applicability of the Revised Universal Soil Loss Equation (RUSLE) to Irish Catchments. Proceedings of the International Association of Hydrological Sciences, 367, 99 - 105. Full text available at: www.proc-iahs.net/367/99/2015/ piahs-367-99-2015.pdf

Sassi, M. G., Hoitink, A. J. F., Vermeulen, B., 2012: Impact of sound attenuation by suspended sediment on ADCP backscatter calibrations. Water Resources Research 48 (9), W09520.

Schmidt-Kloiber, A., Graf, W., Lorenz, A., Moog, O., 2006: The AQEM/STAR taxalist-a pan-European macro-invertebrate ecological database and taxa inventory. Hydrobiologia 566 (1), 325-342.

Schwartz, J. S., Dahle, M., Robinson, B. R., 2008: Concentration-Duration-Fre- quency Curves for Stream Turbidity: Possibilities for Assessing Biological Impairment1. Journal of the American Water Resources Association 44 (4), 879-886.

Sear, D. S., Frostick, L. B., Rollinson, G., Lisle, T. E., 2008: The significance and mechanics of fine-sediment infiltration and accumulation in gravel spawning beds. American Fisheries Society Symposium (65).

Sear, D. A., Pattison, I., Collins, A. L., Newson, M. D., Jones, J. I., Naden, P. S., Carling, P. A., 2014: Factors controlling the temporal variability in dissolved oxygen regime of salmon spawning gravels. Hydrological Processes 28 (1), 86-103.

Turley, M. D., Bilotta, G. S., Extence, C. A., Brazier, R. E., 2014: Evaluation of a fine sediment biomonitoring tool across a wide range of temperate rivers and streams. Freshwater Biology 59 (11), 2268-2277.

Walling, D. E., Webb, B. W., Woodward, J. C., 1992: Some Sampling Considerations in the Design of Effective Strategies for Monitoring Sediment-Associated Transport,in Erosion and Sediment Transport Monitoring Programmes in River Basins, Proceedings of the Oslo Symposium, August 1992 (ed. Bogen, J.). IAHS, Wallingford, Oxfordshire.

Weber, R., Gaus, C., Tysklind, M., Johnston, P., Forter, M., Hollert, H., Heinisch, E., Holoubek, I., LloydSmith, M., Masunaga, S., Moccarelli, P., Santillo, D., Seike, N., Symons, R., Torres, J. P. M., Verta, M., Varbelow, G., Vijgen, J., Watson, A., Costner, P., Woelz, J., Wycisk, P., Zennegg, M., 2008: Dioxin- and POP-Contaminated Sites-Contemporary and Future Relevance and Challenges. Environmental Science and Pollution Research 15 (5), 363-393.

Wetzel, M. A., Wahrendorf, D., von der Ohe, P. C., 2013: Sediment Pollution in the Elbe Estuary and its Potential Toxicity at Different Trophic Levels. Science of the Total Environment 449, 199-207.

Wood, P. J., Toone, J., Greenwood, M. T., Armitage, P. D., 2005: The response of four lotic macroinvertebrate taxa to burial by sediments. ArchivfürHydrobiologie 163 (2), 145-162.

Wright, J. F., Furse, M. T., Moss, D., 1998: River classification using invertebrates: RIVPACS applications. Aquatic Conservation: Marine and Freshwater Ecosystems 8 (4), 617-631. 
D. M. Lawler,

M. A. Wilkes

Towards Improved

Fluvial Sediment

Impact Assessment

(FSIA) approaches within Environmental Impact Assessments

Novi okvir za procjenu utjecaja riječnog sedimenta u studijama utjecaja na okoliš

Damian M. Lawler

Damian.Lawler@coventry.ac.uk

Professor, Centre for Agroecology, Water and Resilience (CAWR), James Starley Building - JS BOI Coventry University, UK Martin A. Wilkes

Research Fellow, Centre for Agroecology, Water and Resilience (CAWR), James Starley Building - JS BO1 Coventry University, UK

Authors

Autori 